\title{
WRF-Chem simulations of a typical pre-monsoon dust storm in northern India: influences on aerosol optical properties and radiation budget
}

\author{
R. Kumar ${ }^{1,2}$, M. C. Barth ${ }^{2}$, G. G. Pfister ${ }^{2}$, M. Naja ${ }^{3}$, and G. P. Brasseur ${ }^{1,4}$ \\ ${ }^{1}$ Advanced Study Program, National Center for Atmospheric Research, Boulder, Colorado, USA \\ ${ }^{2}$ Atmospheric Chemistry Division, National Center for Atmospheric Research, Boulder, Colorado, USA \\ ${ }^{3}$ Aryabhatta Research Institute of Observational Sciences, Nainital, India \\ ${ }^{4}$ Climate Service Center, Helmholtz Zentrum Geesthacht, Hamburg, Germany \\ Correspondence to: R. Kumar (rkumar@ucar.edu)
}

Received: 12 June 2013 - Published in Atmos. Chem. Phys. Discuss.: 23 August 2013

Revised: 16 January 2014 - Accepted: 4 February 2014 - Published: 10 March 2014

\begin{abstract}
The impact of a typical pre-monsoon season (April-June) dust storm event on the regional aerosol optical properties and radiation budget in northern India is analyzed. The dust storm event lasted from 17 to 22 April 2010 and the Weather Research and Forecasting model coupled with Chemistry (WRF-Chem) estimated total dust emissions of $7.5 \mathrm{Tg}$ over the model domain. Both in situ (AERONET - Aerosol Robotic Network) and satellite observations show significant increase (>50\%) in local to regional scale aerosol optical depth (AOD) and decrease (>70\%) in the Angström exponent $(\alpha)$ during this period. Amongst the AERONET sites in this region, Kanpur was influenced the most, where the AOD reached up to 2.1 and the $\alpha$ decreased to -0.09 during the dust storm period. The WRFChem model reproduced the spatial and temporal distributions of dust plumes and aerosol optical properties but generally underestimated the AOD. The average MODIS and WRF-Chem AOD $(550 \mathrm{~nm})$ values in a subregion $\left(70-80^{\circ} \mathrm{E}\right.$, $\left.25-30^{\circ} \mathrm{N}\right)$ affected the most by the dust storm are estimated as $0.80 \pm 0.30$ and $0.68 \pm 0.28$, respectively. Model results show that dust particles cool the surface and the top of the atmosphere, but warm the atmosphere itself. The radiative perturbation due to dust aerosols averaged over the subregion is estimated as $-2.9 \pm 3.1 \mathrm{~W} \mathrm{~m}^{-2}$ at the top of the atmosphere, $5.1 \pm 3.3 \mathrm{~W} \mathrm{~m}^{-2}$ in the atmosphere and $-8.0 \pm 3.3 \mathrm{~W} \mathrm{~m}^{-2}$ at the surface. The simulated instantaneous cooling under the dust plume was much higher and reached -227 and $-70 \mathrm{~W} \mathrm{~m}^{-2}$ at the surface and the top of the atmosphere, re-
\end{abstract}

spectively. The impact of these radiative perturbations on the surface energy budget is estimated to be small on a regional scale but significant locally.

\section{Introduction}

Dust storms frequently occur throughout the desert regions of the world, especially during springtime, injecting large amounts of mineral dust aerosols into the atmosphere. Dust aerosols have a wide range of potential consequences for ambient air quality, global climate, atmospheric chemistry, and biogeochemical processes. Higher levels of particulate matter during dust storms can lead to serious health problems (e.g., Dey et al., 2004; El-Askary et al., 2006). Dust aerosols perturb the Earth's radiation budget directly by interacting with both short- and long-wave radiation (e.g., Seinfeld et al., 2004; Ge et al., 2010; Zhao et al., 2011) and indirectly by modifying cloud microphysics and cloud optical properties (Haywood and Boucher, 2000; Satheesh and Moorthy, 2005). They provide large surfaces for heterogeneous chemistry and deposition of different trace gases (e.g., Dentener et al., 1996; Wang et al., 2012), and influence oceanic and terrestrial biogeochemistry by transporting nutrients like iron (Jickells et al., 2005; Kalenderski et al., 2013). Dust aerosols are ice nuclei and potentially cloud condensation nuclei and can therefore affect cloud properties and precipitation (Miller et al., 2004; Zhao et al., 2011; Teller et al., 2012). Dust aerosols 
can also impact the dynamics of the atmosphere through radiative effects (e.g., Tompkins et al., 2005; Stanelle et al., 2010; Chaboureau et al., 2011).

In general, dust aerosols are emitted from the arid and desert areas around the globe with about $90 \%$ of the total emissions occurring in the Northern Hemisphere (mostly in northern Africa) (Li et al., 2008). Estimates of global total dust emissions by global models are highly uncertain and range from 500 to $6000 \mathrm{Tg} \mathrm{yr}^{-1}$, as reported by the Aerosol Comparisons between Observations and Models (AeroCom) project (Textor et al., 2006; Prospero et al., 2010; Huneeus et al., 2011). Dust aerosols are removed from the atmosphere by dry and wet deposition, with dry deposition removing larger particles near the source regions and wet deposition dominating during long-range transport over the oceanic regions.

Previous observations and simulations show that dust aerosols are not only confined to the source region but can be transported as far as $1000 \mathrm{~km}$ or more (Tegen and Fung, 1994; Ginoux et al., 2001; Prospero et al., 2002; Prospero and Lamb, 2003; Mahowald et al., 2005; Uno et al., 2006; Li et al., 2008), and thus can potentially affect the aerosol optical properties and radiation budget of downwind regions. These impacts of dust aerosols on local to regional scale have been studied in many parts of the world, including India (e.g., Dey et al., 2004; Prasad et al., 2007; Zhao et al., 2010, 2011, Han et al., 2011; Kalenderski et al., 2013). However, the studies over India have only provided information on the local scale, as they focused on integrating in situ observations at a few sites using one dimensional radiative transfer modeling (e.g., Dey et al., 2004; Chinnam et al., 2006; Hegde et al., 2007; Prasad and Singh, 2007; Prasad et al., 2007; Pandithurai et al., 2008; Sharma et al., 2012). Knowledge of the regional scale distribution of dust aerosols and their impact on the regional radiation budget over the Indian region is still very limited.

Dust storms are often observed in the northern part of India where their primary source is the Thar Desert (also known as the Great Indian Desert) located in northwestern India (Washington et al., 2003; Gautam et al., 2009). The dust storms over this region show a distinct seasonal cycle with higher frequency and intensity during the pre-monsoon season (April-June) (Sikka, 1997; Dey et al., 2004; Prasad and Singh, 2007). The generation of dust storms over northern India in the pre-monsoon season is supported by hotter and drier weather conditions (Kumar et al., 2012a). The prevailing westerly/southwesterly winds in the lower atmosphere facilitate the transport of dust aerosols from the Thar Desert to the Indo-Gangetic Plain (IGP) region (Sikka, 1997). The IGP region is one of the most densely populated regions in the world, accommodating 250-1000 people per $\mathrm{km}^{2}$ (CIESIN, http://sedac.ciesin.columbia.edu/gpw), and is a source region of several other types of anthropogenic aerosols, with aerosol loadings 5-8 times higher than those observed at sites outside the IGP region in India (Nair et al., 2007). Elevated dust loadings over the IGP region during the pre-monsoon season have also been seen in satellite data (Prospero et al., 2002; Washington et al., 2003). These dust storms are observed to significantly affect aerosol optical properties over Delhi (Pandithurai et al., 2008), Kanpur (Dey et al., 2004; Prasad and Singh, 2007) and Patiala (Sharma et al., 2012) on the IGP, and Nainital in the central Himalayas (Hegde et al., 2007). These studies, based on observations at a few sites, show an increase in aerosol optical depths by more than $50 \%$, decrease of 70-90\% in Ångström exponent, and a reduction of $50-100 \mathrm{Wm}^{-2}$ in solar radiation reaching the surface.

In light of the above conditions, the main objective of this study is to understand the regional distribution of dust aerosols and their impact on the regional-scale aerosol optical properties and radiation budget during a typical premonsoon dust storm, applying the Weather Research and Forecasting Model coupled with Chemistry (WRF-Chem) to a dust storm event that occurred in northern India during 1722 April 2010. The WRF-Chem model has been used in previous studies over the Indian region and has been shown to capture well the important features of meteorological $(\mathrm{Ku}-$ mar et al., 2012a), chemical (Kumar et al., 2012b; Ghude et al., 2013) and particulate matter distributions (Seethala et al., 2011; Dipu et al., 2013).

The remainder of the manuscript is organized as follows. The WRF-Chem model domain and configuration are described in Sect. 2. Different ground- and satellite-based observations used to understand the influence of the dust storm on aerosol optical properties and to evaluate the model performance are discussed in Sect. 3. The distribution of dust aerosols and their impact on the radiation and surface energy budget are presented in Sect. 4. The findings from this study are summarized in Sect. 5.

\section{The WRF-Chem model}

This study uses version 3.4.1 of the Weather Research and Forecasting Model (Skamarock et al., 2008) coupled with Chemistry (Grell et al., 2005; Fast et al., 2006) to simulate the meteorology and chemistry over the model domain shown in Fig. 1a. The model domain is defined on a Mercator projection and extends from about $56^{\circ} \mathrm{E}$ to $93^{\circ} \mathrm{E}$ (120 grid points) in the east-west direction and from about $17^{\circ} \mathrm{N}$ to $41^{\circ} \mathrm{N}(90$ grid points) in the north-south direction at a horizontal grid spacing of $30 \times 30 \mathrm{~km}^{2}$. The vertical grid is composed of 51 levels from the surface to $10 \mathrm{hPa}(\sim 30 \mathrm{~km})$ with a spacing of about $60 \mathrm{~m}$ near the surface, $200-400 \mathrm{~m}$ for altitudes around $1-3 \mathrm{~km}$ altitudes and $540-600 \mathrm{~m}$ for altitudes around 5$13 \mathrm{~km}$. The static geographical fields, such as terrain height, soil properties, vegetation fraction, land use and albedo, etc., are interpolated from $10 \mathrm{~min}(\sim 19 \mathrm{~km})$ (United States Geological Survey (USGS) data) to the model domain by using the WRF preprocessing system (WPS). The model domain encompasses a widely varying landscape with elevated Himalayan terrain, low altitude $(<500 \mathrm{~m})$ Indo-Gangetic Plain, 

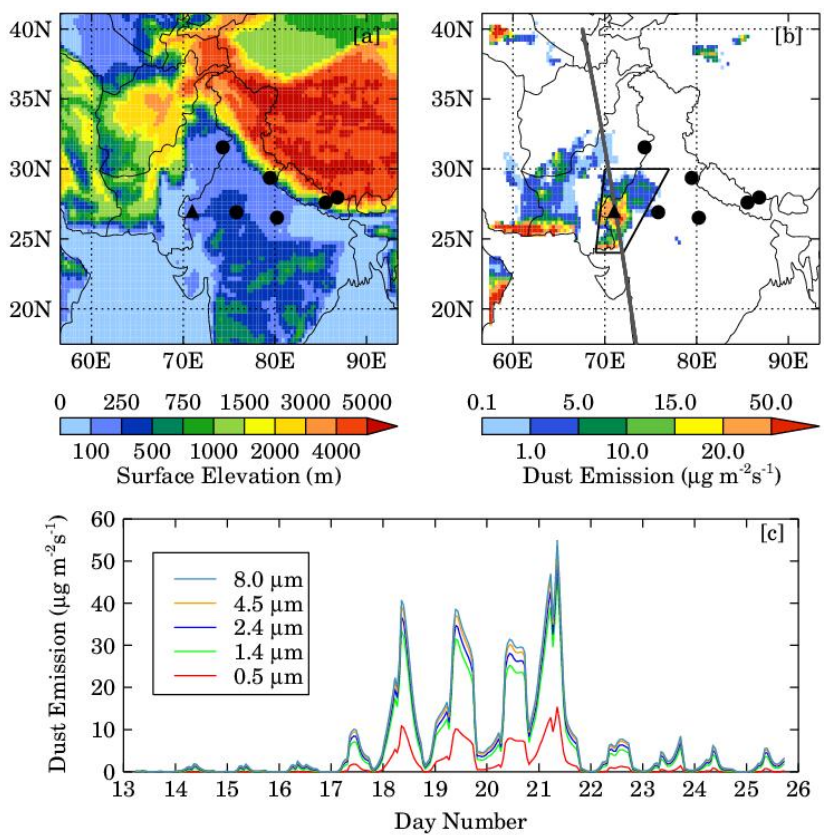

Fig. 1. The WRF-Chem model domain showing (a) topography and (b) spatial distribution of dust emissions averaged over 13-25 April 2010. Black circles show the geographical location of AERONET sites and the black triangle shows the location where the time series of dust emissions from WRF-Chem is shown in (c) for the period of 13-25 April 2010. (b) Also shows the location of Thar Desert (enclosed by solid black lines) and CALIPSO satellite overpass (grey line) over the model domain on 20 April 2010.

semi-arid and desert land masses and seashores (Fig. 1a and b). This complex terrain has an important influence on the meteorology and the distribution of chemical species.

The initial and lateral boundary conditions for the meteorological fields are obtained from the National Center for Environmental Predictions (NCEP) Final Analysis (FNL) fields available every $6 \mathrm{~h}$ at a spatial resolution of $1^{\circ} \times 1^{\circ}$. The resolved scale cloud physics is represented by the Thompson microphysics scheme (Thompson et al., 2004) and sub-grid scale effects of convective and shallow clouds are parameterized according to the Kain-Fritsch convective scheme (Kain, 2004). The short- and long-wave radiative transfer in the atmosphere is represented by the Rapid Radiative Transfer Model (RRTM) (Mlawer et al., 1997), which allows for online interaction between aerosols and meteorology in the model. For surface processes, the model setup uses the NOAH Land Surface model (Chen and Dudhia, 2001) and MM5 similarity scheme (Beljaars, 1994). The vertical sub-grid scale fluxes due to eddy transport in the planetary boundary layer (PBL) and the free troposphere are parameterized according to the Yonsei University (YSU) boundary layer scheme (Hong et al., 2006).

Four dimensional data assimilation (FDDA) technique is also applied to limit the model errors in the simulated me- teorological fields (Lo et al., 2008) because the production and transport of dust aerosols depend crucially on the accuracy of simulated meteorology. The horizontal winds, moisture and temperature are nudged at all vertical levels with a nudging coefficient of $6 \times 10^{-4} \mathrm{~s}^{-1}$. The choice of nudging the whole depth of the model atmosphere was inspired by the study of Deng et al. (2006), who showed that the WRF model with nudging at all the levels performs better in simulating the meteorological variables (temperature, water vapor, wind speed and direction) as compared to without nudging in the planetary boundary layer (PBL). We also find that the nudging at all model levels gives better correlation with observed aerosol optical properties as compared to a simulation with nudging only above the PBL and a simulation without nudging. The temperature and pressure show a mixed response to FDDA with changes of $\pm 2 \mathrm{~K}$ and $\pm 1 \mathrm{~g} \mathrm{~kg}^{-1}$ while wind speed generally decreases over the model domain due to FDDA. The difference in wind speed is especially higher over the Thar Desert region $\left(2-3 \mathrm{~m} \mathrm{~s}^{-1}\right)$. The change in wind speed has direct consequences for dust emissions, which are discussed later in this section. Analysis of other consequences of analysis nudging through changes in dust emissions and their subsequent impacts on aerosol budget, their optical properties, photolysis rates and tropospheric chemistry deserves to be examined in a separate study and is not analyzed here.

The gas-phase chemistry is represented by the Model for Ozone and Related Chemical Tracers (MOZART-4) chemical scheme (Emmons et al., 2010) and the aerosol processes are represented by the Goddard Chemistry Aerosol Radiation and Transport (GOCART) bulk aerosol scheme (Chin et al., 2002; Pfister et al., 2011). The bulk aerosol mass simulated by GOCART scheme is converted into assumed modal distributions and divided into eight size bins in the model to allow for interaction between GOCART aerosols and radiation. The initial and lateral boundary conditions for the chemical species are provided from six hourly output of MOZART4 (Emmons et al., 2010). Anthropogenic emissions of CO, $\mathrm{NO}_{\mathrm{x}}, \mathrm{SO}_{2}, \mathrm{NH}_{3}, \mathrm{OC}$ and $\mathrm{BC}$ and non-methane volatile organic compounds (NMVOC) are taken from the European MACC (Monitoring Atmospheric Composition and Climate) project's MACCity emissions inventory (Granier et al., 2011), and emissions for $\mathrm{PM}_{2.5}$ and $\mathrm{PM}_{10}$ are taken from the Intercontinental Chemical Transport Experiment - Phase B (INTEX-B) inventory (Zhang et al., 2009). Daily varying emissions of trace species from biomass burning are taken from the Fire Inventory from NCAR version 1 (FINN v1) (Wiedinmyer et al., 2011) and distributed vertically in the model following the online plume-rise module (Freitas et al., 2007). Note that FINN v1 accounts only for open biomass burning and the residential biomass burning is included in anthropogenic emissions. Biogenic emissions of trace species from terrestrial ecosystems are calculated online using the Model of Emissions of Gases and Aerosols from Nature (MEGAN) version 2.04 (Guenther et al., 2006). The aerosols 
are allowed to provide feedback to the radiation scheme in the simulations but through direct effects only.

The GOCART scheme (Ginoux et al., 2001) calculates the dust emission flux online in the model by using the following expression:

$F_{p}= \begin{cases}C S s_{p} u_{10 \mathrm{~m}}^{2}\left(u_{10 \mathrm{~m}}-u_{\mathrm{t}}\right) & \text { if } u_{10 \mathrm{~m}}>u_{\mathrm{t}} \\ 0 & \text { otherwise }\end{cases}$

where $F_{p}\left(\mathrm{~kg} \mathrm{~m}^{-2} \mathrm{~s}^{-1}\right)$ represents the emission flux for size bin $p, C$ is an empirical proportionality constant $\left(\mathrm{kg} \mathrm{m}^{-5} \mathrm{~s}^{2}\right)$, $S$ is the source function representing the fraction of alluvium available for wind erosion, $s_{p}$ is the fraction of each size class of dust in the emission, $u_{10 \mathrm{~m}}\left(\mathrm{~m} \mathrm{~s}^{-1}\right)$ is the horizontal wind speed at $10 \mathrm{~m}$ above the surface, and $u_{\mathrm{t}}$ is the threshold velocity $\left(\mathrm{m} \mathrm{s}^{-1}\right)$ below which dust emission does not occur and is a function of particle size, air density and surface moisture. The value of $C$ was proposed initially as $1 \times 10^{-9} \mathrm{~kg} \mathrm{~m}^{-5} \mathrm{~s}^{2}$ (Ginoux et al., 2001) but is suggested to be highly tuneable. Previous studies over the Sahara (Zhao et al., 2010) and Arabian Peninsula (Kalenderski et al., 2013) found the model AOD greater than observations, thus requiring a decrease in dust emissions, which was achieved by reducing $C$ to $0.4-0.65 \times 10^{-9} \mathrm{~kg} \mathrm{~m}^{-5} \mathrm{~s}^{2}$. In contrast, the default $\mathrm{C}$ value is found to yield very low dust emissions over the Indian region (Dipu et al., 2013).

Here, we used AOD $(500 \mathrm{~nm})$ and Angström exponent $(\alpha)$ observations at seven Aerosol Robotic Network (AERONET) sites in the model domain to constrain the $C$ value and dust emissions in northern India. Several sensitivity experiments suggest that a $C$ value of $2.2 \times 10^{-8} \mathrm{~kg} \mathrm{~m}^{-5} \mathrm{~s}^{2}$ leads to the best agreement between modeled and observed AOD $(500 \mathrm{~nm})$ and $\alpha$ at all these sites. It should be noted that this large increase (by a factor of 22) in the $C$ value is partly due to use of FDDA in the present model configuration as FDDA nudges simulated wind fields towards analysis fields and thus leads to lower wind speeds. A sensitivity experiment showed that similar dust emission can be obtained with a $C$ value of $9 \times 10^{-9} \mathrm{~kg} \mathrm{~m}^{-5} \mathrm{~s}^{2}$ without the use of FDDA. But we chose to use FDDA as the model configuration with FDDA is found to better reproduce the variations in observed aerosol optical properties as compared to one without FDDA (not shown). The time series of dust emission at a location $\left(71^{\circ} \mathrm{E}, 27^{\circ} \mathrm{N}\right)$ in the Thar Desert (indicated by a black triangle in Fig. 1a and b) is shown in Fig. 1c. The dust outbreak started on 17 April 2010, reached its maximum intensity on 21 April 2010 and ended on 22 April 2010. The total dust emissions over the model domain are estimated to be $11.8 \mathrm{Tg}$ during 13-25 April 2010, out of which 7.5 Tg of dust was emitted during 17-22 April 2010 with emissions reaching as high as $2.1 \mathrm{Tg}$ on 20 April 2010.

The model simulation began on 10 April 2010 at 00:00 UTC and ended on 25 April 2010 at 12:00 UTC, with model output every hour. The WRF-Chem model with this configuration has been evaluated in detail and found to reproduce the meteorological features of this region fairly well
(Kumar et al., 2012a). Two simulations, with and without dust aerosols, are conducted to assess the impact of the dust storm on aerosol optical properties and the radiation budget. The model results for the first three days are discarded as model spin up and those after 13 April 2010 are used for further analysis.

\section{Observation techniques and data}

\subsection{Aerosol Robotic Network (AERONET) data}

The Aerosol Robotic Network (AERONET) (Holben et al., 1998) is a ground-based remote sensing aerosol network of more than 1000 sites established by the National Aeronautics and Space Administration (NASA), which uses Sun- and sky-scanning radiometers to measure aerosol optical properties (Dubovik and King, 2000). This study uses AERONET version 2, level 2 cloud-screened and quality assured aerosol optical depth (AOD) at 500 nm, Ångström exponent $(440-870 \mathrm{~nm})$, and single scattering albedo (SSA) at $675 \mathrm{~nm}$ from seven sites in the model domain for studying the impact of the dust storm on aerosol optical properties and for comparison with model results. The geographical locations of these seven sites are shown in Fig. 1a and b. These seven sites are Kanpur $\left(80.23^{\circ} \mathrm{E}, 26.51^{\circ} \mathrm{N}, 123 \mathrm{~m}\right)$, Nainital $\left(79.46^{\circ} \mathrm{E}, 29.36^{\circ} \mathrm{N}, 1939 \mathrm{~m}\right)$, Jaipur $\left(75.81^{\circ} \mathrm{E}\right.$, $\left.26.91^{\circ} \mathrm{N}, 450 \mathrm{~m}\right)$, Lahore $\left(74.32^{\circ} \mathrm{E}, 31.54^{\circ} \mathrm{N}, 270 \mathrm{~m}\right)$, Kathmandu University $\left(85.54^{\circ} \mathrm{E}, 27.60^{\circ} \mathrm{N}, 1510 \mathrm{~m}\right)$, EVK2CNR $\left(86.813^{\circ} \mathrm{E}, 27.96^{\circ} \mathrm{N}, 5050 \mathrm{~m}\right)$ and Pokhara $\left(83.97^{\circ} \mathrm{E}\right.$, $28.15^{\circ} \mathrm{N}, 807 \mathrm{~m}$ ) (Fig. 1a and b). These seven sites allow for the model evaluation in different chemical environments, with Kanpur, Jaipur, Lahore, Kathmandu and Pokhara representing urban conditions while Nainital and EVK2-CNR represent cleaner higher altitude environments. The uncertainty of AERONET AOD measurements is reported to be about \pm 0.01 for AOD at wavelengths greater than $440 \mathrm{~nm}$ (Holben et al., 1998).

\subsection{Satellite data}

This study uses the NASA Sea viewing Wide Field of view Sensor (SeaWiFS) Level 3 "Deep Blue" $550 \mathrm{~nm}$ AOD retrievals at spatial resolution of $0.5^{\circ} \times 0.5^{\circ}$, and NASA Moderate Resolution Imaging Spectroradiometer (MODIS) Collection 5.1 "Deep Blue" $550 \mathrm{~nm}$ Level 3 AOD retrievals at spatial resolution of $1^{\circ} \times 1^{\circ}$, and Level 2 retrievals at $10 \mathrm{~km}$ resolution. The Ozone Monitoring Instrument (OMI) retrieved Level 3 ultraviolet aerosol index at a spatial resolution of $0.25^{\circ} \times 0.25^{\circ}$ and Cloud-Aerosol Lidar and Infrared Pathfinder Satellite Observation (CALIPSO) retrieved Level 2 profiles of extinction coefficient at $532 \mathrm{~nm}$ are also used. The SeaWiFS and MODIS instruments measure Earth's spectral radiance in $412-865 \mathrm{~nm}$ and $400-14400 \mathrm{~nm}$ wavelength ranges, respectively. The standard MODIS aerosol retrieval algorithm does not retrieve aerosol information over 
bright surfaces such as the Thar Desert due to strong surface spectral contribution in the visible range (Kaufman et al., 1997). For this reason, we use the recently developed "Deep Blue" AOD retrievals at $550 \mathrm{~nm}$ over land from MODIS (collection 5.1) aboard Aqua (Hsu et al., 2004), which is able to retrieve AOD over such bright surfaces. The OMI ultraviolet aerosol index is retrieved from the backscattered radiation measured by the OMI in $270-500 \mathrm{~nm}$ wavelength range. The ultraviolet aerosol index is not an optical depth but is a useful index for separating the absorbing and scattering aerosols with negative and near-zero values associated with scattering aerosols and values greater than 1 associated with absorbing aerosols. CALIPSO integrates an active lidar instrument with passive infrared and visible imagers to probe vertical structure of aerosols and clouds. The acquired lidar backscatter profiles are calibrated and range registered to identify cloud and aerosol layers, and retrieve aerosol extinction coefficients at $532 \mathrm{~nm}$ and $1064 \mathrm{~nm}$. Detailed information on CALIPSO retrieved aerosol products can be seen in Winker et al. (2013) and references therein.

\subsection{Evaluation methodology}

The aerosol optical properties in WRF-Chem are available at 300, 400, 600 and $999 \mathrm{~nm}$ while AOD from AERONET and satellite data are available at 500 and $550 \mathrm{~nm}$, respectively; AERONET SSA at $675 \mathrm{~nm}$ is used. In order to derive the model AOD at 500 and $550 \mathrm{~nm}$, the Ångström power law is used:

$W(\lambda)=W(400) \times\left(\frac{\lambda}{400}\right)^{-\alpha}$,

where $W(\lambda)$ is the WRF-Chem AOD at wavelength $\lambda(500$ or 550) nm and $\alpha$ is the Ångström exponent calculated from WRF-Chem AOD at 300 and $999 \mathrm{~nm}$ using the following relation:

$\alpha=\frac{\ln \left(\frac{W(300)}{W(999)}\right)}{\ln \left(\frac{999}{300}\right)}$.

The Eqs. (2) and (3) are consistent with the WRF-Chem framework as the model also uses these equations to interpolate/extrapolate the AOD (300-999 nm) to RRTM spectra $(0.2-12 \mu \mathrm{m})$ for aerosol-radiation interaction in the model. The model SSA at $675 \mathrm{~nm}$ is derived by linearly interpolating model SSA between 300 and $999 \mathrm{~nm}$. The WRF-Chem AOD and SSA are matched with AERONET/satellite data in space and time using a bilinear interpolation of the four nearest model grid points. The co-located model and observed data are then used for further analysis.

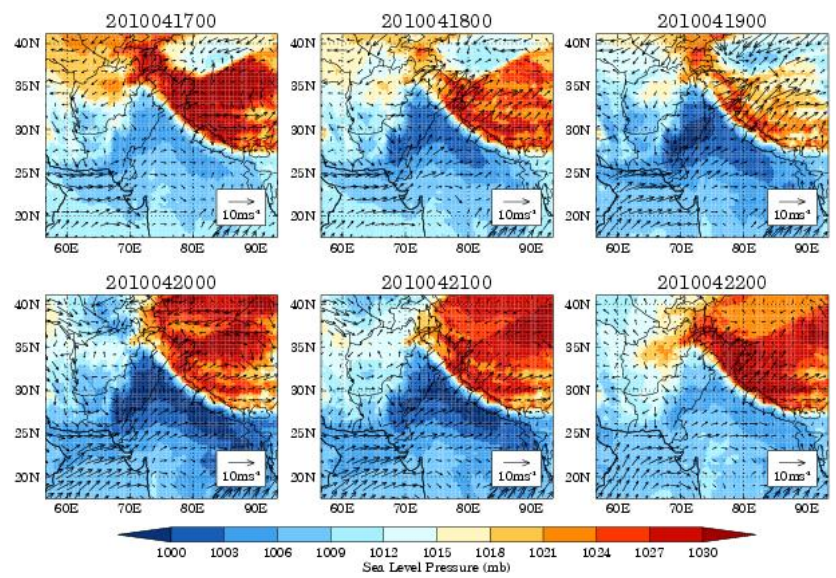

Fig. 2. Day-to-day variations in mean sea level pressure and $10 \mathrm{~m}$ wind vectors over the model domain from 17 to 22 April 2010 at 00:00 UTC. The wind vectors are shown every 5th grid point for clarity.

\section{Results and discussion}

\subsection{General meteorology}

This section discusses the general meteorological features of the northern Indian region to understand the cause of this dust storm. The average modeled temperature and relative humidity over the Thar Desert and IGP region during 13-25 April are estimated as $31-35^{\circ} \mathrm{C}$ and $10-20 \%$, respectively, and the total rainfall is estimated to be less than $10 \mathrm{~mm}$ over both these regions, indicating the presence of hot and dry conditions during this period. The modeled spatial distribution of sea level pressure along with $10 \mathrm{~m}$ wind vectors from 17 to 22 April 2010 at 00 GMT are shown in Fig. 2. The winds blowing into the Thar Desert were mostly southwesterly and changed to westerly/northwesterly while moving along the IGP. The sea level pressure shows the presence of a low pressure system over the IGP on 17 April, increasing in strength from 17 through 21 April. This low pressure system generated strong winds, which in turn led to higher dust emissions during this period (Fig. 1c). The sea level pressure increased on 22 April and consequently the wind speed and dust emissions decreased. However, AOD levels at some AERONET sites were still high on 22 April (Sect. 4.3) despite the decreased dust emission, and thus further analysis in this study is restricted to the period of 17-22 April 2010, unless stated otherwise.

The spatial distributions of the daytime (09:30-16:30 IST or 04:00-11:00 UTC) average planetary boundary layer (PBL) height and tropopause height above ground level over the model domain during 17-22 April 2010 are shown in Fig. 3 to help the interpretation of the PBL and free tropospheric dust loading calculations shown in Sect. 4.2. The tropopause altitude is determined using the thermal tropopause definition (Reichler et al., 2003) and the PBL 


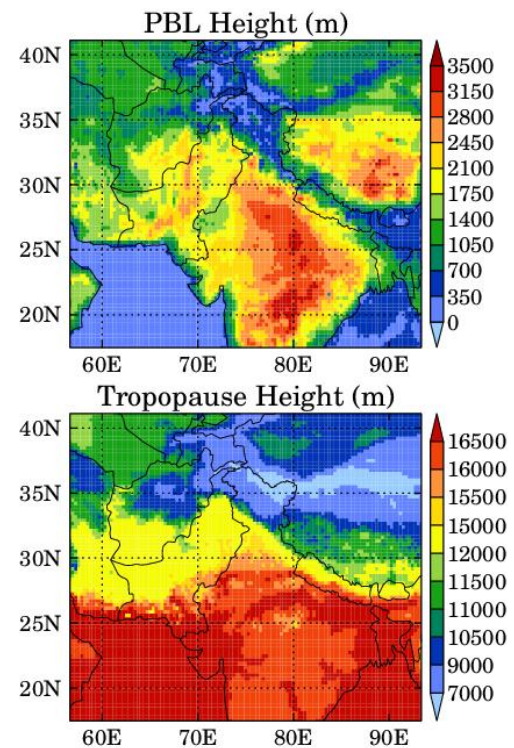

Fig. 3. Spatial distributions of WRF-Chem simulated daytime (09:30 to 16:30 IST) average planetary boundary layer (PBL) and tropopause height over the model domain during 17-22 April 2010. Indian standard time (IST) is $5.5 \mathrm{~h}$ ahead of UTC.

height is the level of minimum entrainment flux calculated by the YSU PBL scheme. The daytime average PBL height is $1500-3500 \mathrm{~m}$ over the Indian region and shows strong diurnal variability with daytime heights reaching up to 3000 $5000 \mathrm{~m}$ and nighttime values remaining below $500 \mathrm{~m}$. The average PBL height over the oceanic regions shows little diurnal variation and on average is $150-600 \mathrm{~m}$. The average tropopause height is $12-17 \mathrm{~km}$ over regions south of $30^{\circ} \mathrm{N}$ and decreases to $7-12 \mathrm{~km}$ for $30-40^{\circ} \mathrm{N}$.

\subsection{Spatial and vertical distribution of dust}

The natural color image captured by MODIS aboard Aqua on 21 April 2010 at 0745 GMT shows an event of dust blowing through northern India (Fig. 4). This natural color image is used to examine the ability of WRF-Chem in simulating the transport of dust which is done by comparing to the modeled column integrated dust loading for particles with effective radius of $2.4 \mu \mathrm{m}$ and $10 \mathrm{~m}$ wind vectors. The comparison shows that WRF-Chem reproduces the spatial pattern of the dust plume on this day fairly well. Both MODIS and WRFChem show dust blowing along the Indo-Pakistan border and changing direction just west of the Himalayas, followed by southward transport along the Indo-Gangetic Plain alongside the southern face of the Himalayas. The role of southwesterly winds in redistributing dust is consistent with previous studies (Sikka, 1997; Dey et al., 2004; Prasad and Singh, 2007).

To examine where the dust emitted from the Thar Desert was transported, the spatial distributions of WRF-Chem simulated daytime (09:30 to 16:30 LT) average dust loadings in the boundary layer and free troposphere over the model do-
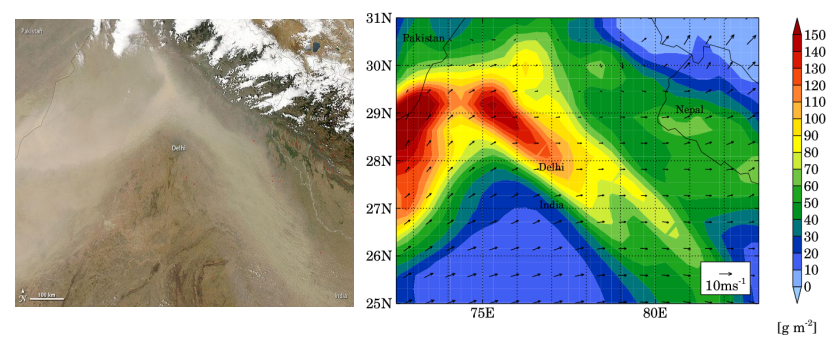

Fig. 4. Natural color image captured by Moderate Resolution Imaging Spectroradiometer (MODIS) aboard Aqua on 21 April 2010 at 07:45 GMT (left panel) and WRF-Chem simulated spatial distribution of column integrated dust loading at $2.4 \mu \mathrm{m}$ and $10 \mathrm{~m}$ wind vectors over the model domain on 21 April 2010 at 08:00 GMT (right panel). The wind vectors are shown every second grid point for clarity. Both the images cover same spatial extent.

main during 17-22 April 2010 are shown in Fig. 5 for dust particles of $0.73 \mu \mathrm{m}, 2.4 \mu \mathrm{m} 8.0 \mu \mathrm{m}$ effective radii, representing small, coarse and giant mode dust particles, respectively. The dust loadings in the boundary layer and free troposphere are obtained every hour by integrating dust mass concentrations from the surface to the top of the PBL, and from the PBL height to the tropopause height, respectively. Dust loading distributions in the boundary layer are consistent with patterns of dust emissions with highest values over the source region (Thar Desert) and nearby downwind regions (western IGP). The average dust loading ranges for small, coarse and giant mode particles are $0-32,0-60$ and $0-40 \mathrm{~g} \mathrm{~m}^{-2}$, respectively. The small and coarse mode dust particles show similar distributions but coarse particles are mostly responsible for the higher dust loadings over the Thar Desert and western IGP region. This is consistent with observations detecting a small change in fine mode particles and large increases ( $\sim 3$ times) in coarse mode aerosols at Kanpur during dust storms (Dey et al., 2004). The giant mode particle distribution shows higher concentrations only in the source regions because they quickly fall back to the surface and are not transported over longer distances. The domain-averaged total dust loadings in the daytime boundary layer are estimated as $21 \pm 42 \mathrm{~g} \mathrm{~m}^{-2}$, out of which $68 \%$ is attributed to dust emissions for 1.4 and $2.4 \mu \mathrm{m}$ effective radii.

The dust loadings in the free troposphere are lower than those in the boundary layer and range from $0-12$ and $0-22 \mathrm{~g} \mathrm{~m}^{-2}$ for small and coarse mode particles, respectively. The giant particles are not lifted to the free troposphere and their contributions are less than $2 \mathrm{~g} \mathrm{~m}^{-2}$. Small and coarse mode dust particles in the free troposphere are distributed over a wider spatial extent relative to the boundary layer because free tropospheric winds are stronger and more efficient in transporting dust plumes. Additionally, the influence of emissions sources is reduced in the free troposphere and the lifetime of dust particles increases as they become less susceptible to dry deposition. Interestingly, free tropospheric 

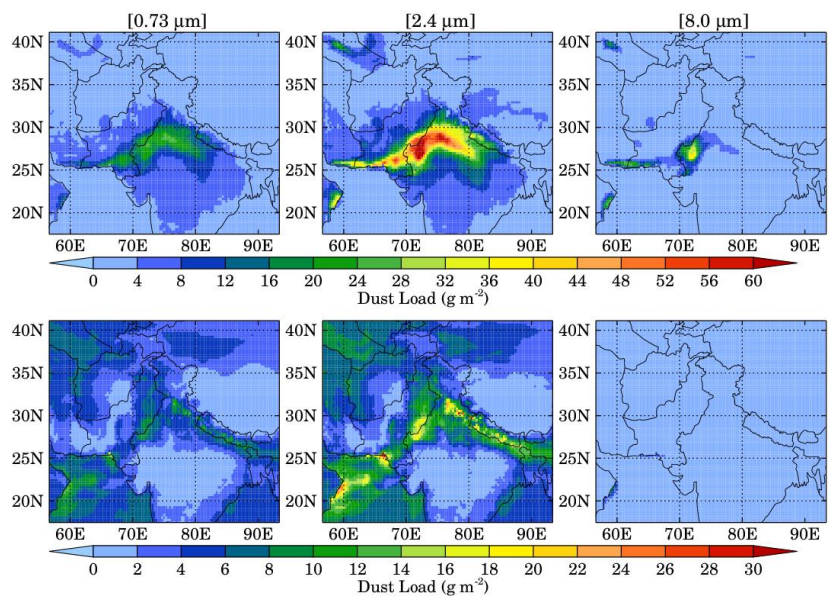

Fig. 5. Spatial distributions of WRF-Chem simulated daytime (09:30 to 16:30 IST) average boundary layer (top panels) and free tropospheric (bottom panels) integrated dust load over the model domain during 17-22 April 2010. The distributions are shown at $0.73,2.4$ and $8.0 \mu \mathrm{m}$ effective radii, representing accumulation, coarse and giant mode dust particles, respectively.

dust loadings over some regions such as the Arabian Sea are higher than in the boundary layer, indicating that longrange transport of dust particles may play an important role in aerosol radiative effects in the free troposphere. The domainaveraged total dust loading in the daytime free troposphere is estimated to be $19 \pm 22 \mathrm{~g} \mathrm{~m}^{-2}$, out of which $71 \%$ comes from the dust emissions for 1.4 and $2.4 \mu \mathrm{m}$ effective radii.

The time series for 17-22 April of the vertical distribution of average mass concentration of dust particles with 0.73 , $1.4,2.4,4.5$ and $8.0 \mu \mathrm{m}$ effective radii spatially averaged over the area of $70-80^{\circ} \mathrm{E}$ and $25-30^{\circ} \mathrm{N}$ to examine the altitude attained by the dust plumes (shown in Fig. 6). This region is chosen because the dust storm had maximum influence in this region. We also include the spatially averaged planetary boundary layer height in the graphs. Average PBL height over this region varies from about $50 \mathrm{~m}$ during nighttime to about $3200 \mathrm{~m}$ during daytime. The simulated PBL cannot be evaluated due to the lack of observations. Dust mass concentrations in all five size bins show a sharp vertical gradient with values higher in the PBL $\left(60-300 \mu \mathrm{g} \mathrm{m}^{-3}\right.$ ) compared to the free troposphere $\left(<200 \mu \mathrm{g} \mathrm{m}^{-3}\right)$. Above $5000 \mathrm{~m}$ the dust mass concentration decreases to less than $20 \mu \mathrm{g} \mathrm{m}^{-3}$.

Dust mass concentrations near the surface show a strong diurnal cycle with highest values during nighttime (Fig. 6). Even though the dust emissions show peak values around local noon (Fig. 1c), higher nighttime values indicate the dominant role of the PBL in controlling the diurnal variability of dust mass concentrations. The shallow boundary layer traps dust particles near the surface during nighttime but the growth of the boundary layer during daytime allows substantial mixing of dust particles over a large volume and thus dust mass concentrations show a decrease during daytime.
The overpass of CALIPSO over this region on 20 April 2010 at 08:15 UTC (see Fig. 1b) allows us to evaluate the height of the dust plume in the model. The time-altitude image of aerosol subtypes retrieved by CALIPSO shown in bottom panel of Fig. 6 clearly shows the presence of dust aerosols up to an altitude of $5000 \mathrm{~m}$. The WRF-Chem simulated extinction coefficient at $550 \mathrm{~nm}$ on 20 April 2010 at 08:00 UTC is extracted along the CALIPSO track and compared with CALIPSO retrieved extinction coefficient at $532 \mathrm{~nm}$ in Fig. 7. The best quality CALIPSO retrievals are selected for comparison, following the guidelines provided by the CALIPSO science team. In general, WRFChem underestimates the extinction coefficient retrieved by CALIPSO but captures the spatial and vertical variations along the CALIPSO track. The underestimation of extinction coefficient might be related to large uncertainties reported in anthropogenic emissions (Cherian et al., 2012; Nair et al., 2012) and modeled meteorology. The extinction coefficient increase from $0.03-0.4 \mathrm{~km}^{-1}$ in $18-23^{\circ} \mathrm{N}$ latitude band to $0.4-1 \mathrm{~km}^{-1}$ over the Thar Desert $\left(24-29^{\circ} \mathrm{N}\right)$ region in both the CALIPSO and WRF-Chem. Like vertical distribution of dust, the WRF-Chem extinction coefficient also shows a sharp decrease in extinction coefficient with values of more than $0.5 \mathrm{~km}^{-1}$ near the surface and values lower than $0.3 \mathrm{~km}^{-1}$ above $4 \mathrm{~km}$. Even though the CALIPSO data do not extend to the surface, a sharp decrease in the CALIPSO extinction coefficient is also discerned.

\subsection{Impact of dust storm on aerosol optical properties}

The time series of WRF-Chem simulated aerosol optical depth at $500 \mathrm{~nm}$ and Ångström exponent $(\alpha)$ at seven sites in the model domain are compared with co-located AERONET observations during 13-25 April 2010 (Fig. 8). AOD represents the integrated extinction (absorption + scattering) coefficient over a vertical column of unit cross section and $\alpha$ describes the dependency of AOD on wavelength and is inversely related to aerosol size with smaller values for larger particles and vice-versa. Note that $\alpha$ for AERONET measurements is available for the $470-880 \mathrm{~nm}$ wavelength range while $\alpha$ for the model is calculated from AOD at 300 and $999 \mathrm{~nm}$ using Eq. (3). Both observation and model data show a significant increase in AOD and decrease in $\alpha$ at Kanpur and Nainital during 17-22 April, indicating that these sites were impacted the most by the dust plumes. The dust emissions decreased on 22 April (Fig. 1c) but AOD at Kanpur and Nainital was still somewhat elevated on the following days, indicating the lingering impact of dust aerosols in the region.

Observed AOD at Kanpur reaches as high as 2.1 and $\alpha$ reaches as low as -0.09 . The simulated AOD does not reach the magnitude of the observed peaks at Kanpur, but captures the temporal evolution and simulates well the low values of $\alpha$. The observed and model average $500 \mathrm{~nm}$ AOD at Kanpur during 17-22 April 2010 are estimated as $1.07 \pm 0.40$ and $0.64 \pm 0.26$, respectively, and the corresponding $\alpha$ values 

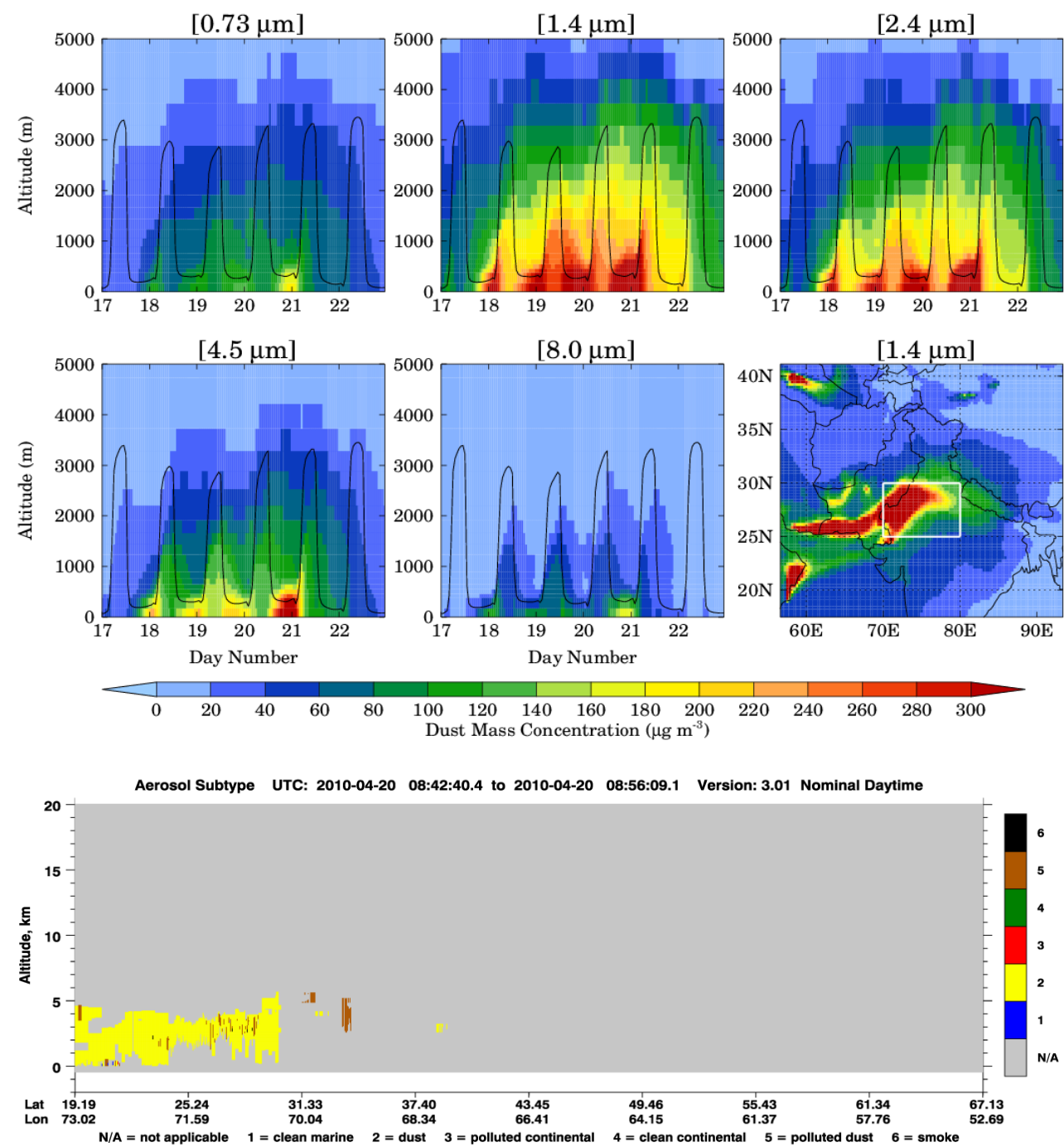

Fig. 6. Vertical distributions of mass concentration of dust particles with $0.73,1.4,2.4,4.5$ and $8.0 \mu$ m effective radii during 17-22 April 2010. The black lines represent the temporal variations of average PBL height. The geographical region $\left(70-80^{\circ} \mathrm{E}, 25-30^{\circ} \mathrm{N}\right)$ over which dust mass concentrations and PBL height are averaged is shown by white outlined box in the figure in rightmost middle panel, which also shows the spatial distributions of dust mass concentration at $1.4 \mu \mathrm{m}$ at the surface. The time-altitude image of aerosol subtypes retrieved by CALIPSO on 20 April 2010 (see track in Fig. 1b) is shown in bottom panel.

are estimated as $0.06 \pm 0.14$ and $0.12 \pm 0.18$, respectively. In contrast to Kanpur, the model overestimates AOD at Nainital, particularly during 18-19 April, but is in very good agreement with observations during 20-22 April and captures well the lowest $\alpha$ values. The observed and model average $500 \mathrm{~nm}$ AOD at Nainital are estimated as $0.61 \pm 0.17$ and $0.73 \pm 0.22$, respectively, and the corresponding $\alpha$ values are $0.26 \pm 0.24$ and $0.18 \pm 0.24$, respectively.

These average AOD values are significantly higher and $\alpha$ values are significantly lower than the seasonal (MAM) mean values reported at Kanpur (AOD: $0.54 \pm 0.26, \alpha: 0.6 \pm 0.31$; Singh et al., 2004) and Nainital (AOD: $0.29 \pm 0.03, \alpha: 0.5-$ 0.9; Sagar et al., 2004), but the values reported here are commonly observed during dust storms events (Dey et al., 2004;
Prasad and Singh, 2007; Hegde et al., 2007). This suggests that the dust storm of 17-22 April 2010 was a typical premonsoon dust storm. AOD values at other sites do not show a significant increase during the dust storm. A slight decrease in $\alpha$ indicates that these sites are also influenced by the dust storm but likely by thinner dust plumes.

The correlation coefficient between model and observations for AOD at all the sites ranges from 0.58 to 0.80 , except at EVK2-CNR $(r=-0.04)$ and Pokhara $(r=-0.16)$. However, the correlation coefficient for $\alpha$ is found to range from 0.55 to 0.88 at all sites, indicating that WRF-Chem is able to qualitatively reproduce the observed variations in particle size. The model also overestimates the AOD at Nainital despite the good correlation between model and 

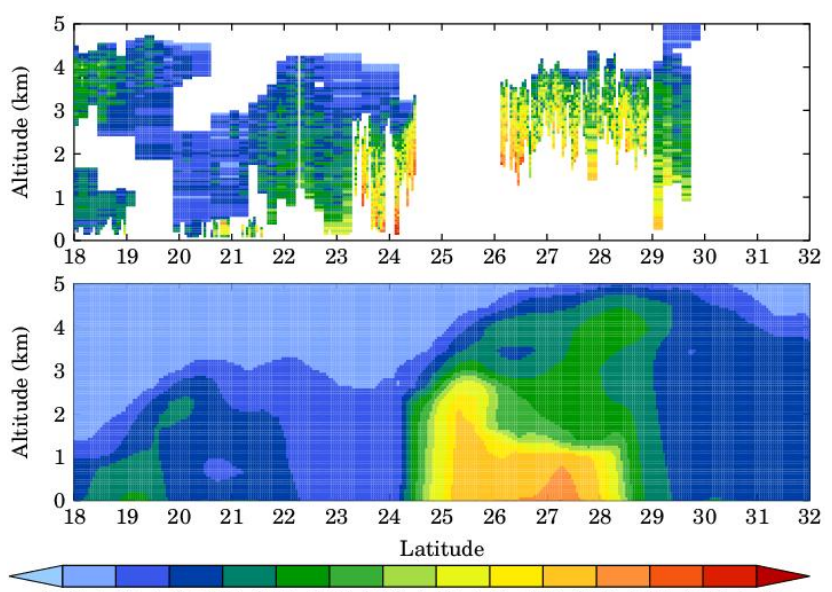

$\begin{array}{llllllllllllll}0.00 & 0.03 & 0.06 & 0.10 & 0.15 & 0.20 & 0.25 & 0.30 & 0.40 & 0.50 & 0.75 & 1.00 & 2.00 & 5.00\end{array}$ Extinction Coefficient $\left(\mathrm{km}^{-1}\right)$

Fig. 7. Comparison of CALIPSO retrived extinction coefficient at $532 \mathrm{~nm}$ (top panel) with WRF-Chem simulated extinction coefficient at $550 \mathrm{~nm}$ (lower panel) on 20 April 2010.

observations for both AOD and $\alpha$. The sites of Pokhara, EVK2-CNR and Nainital represent different chemical environments, with Pokhara ( $\sim 800 \mathrm{~m}$ a.m.s.l.) being a low altitude site and the second biggest city of Nepal with a population of about 200000 people, representing an urban environment, whereas EVK2-CNR $(\sim 5050$ m a.m.s.l.) and Nainital $(\sim 1939$ m a.m.s.l.) are high altitude sites located far from the major anthropogenic activities in the Himalayas, representing cleaner environments. This indicates that the uncertainties in aerosol emissions could be a major contributor to the model bias at Pokhara whereas errors in modeled transport processes could be of more importance for EVK2-CNR. However, a quantification of the relative contribution of these factors is not possible here due to lack of suitable aerosol and meteorological measurements. The horizontal grid spacing of the model is another important factor affecting the simulated trace species in the model domain, especially in the Himalayan region. Note that the sites of EVK2-CNR (5050 m), Nainital (1936 m) and Pokhara (807 m) are located in the region of rapidly varying topography (Fig. 1a), and modeled altitude of these sites is estimated to be off by $400-900 \mathrm{~m}$. The errors in model topography will induce errors in modeled meteorology and thus transport of aerosols to these sites. However, the coarse grid spacing $(50 \mathrm{~km})$ of MACCity emission inventory used here limits the applicability of model at a much finer grid spacing $(<10 \mathrm{~km})$. The lack of a secondary organic aerosol formation scheme in the current model setup might also have some contribution to the model-observation discrepancies.

The WRF-Chem simulated single scattering albedo (SSA) values are also compared to AERONET observed SSA at $675 \mathrm{~nm}$. There are very few SSA observations available at the AERONET sites and more than 10 data points are available only at Kanpur $(N=31)$, Nainital $(N=24)$, Lahore

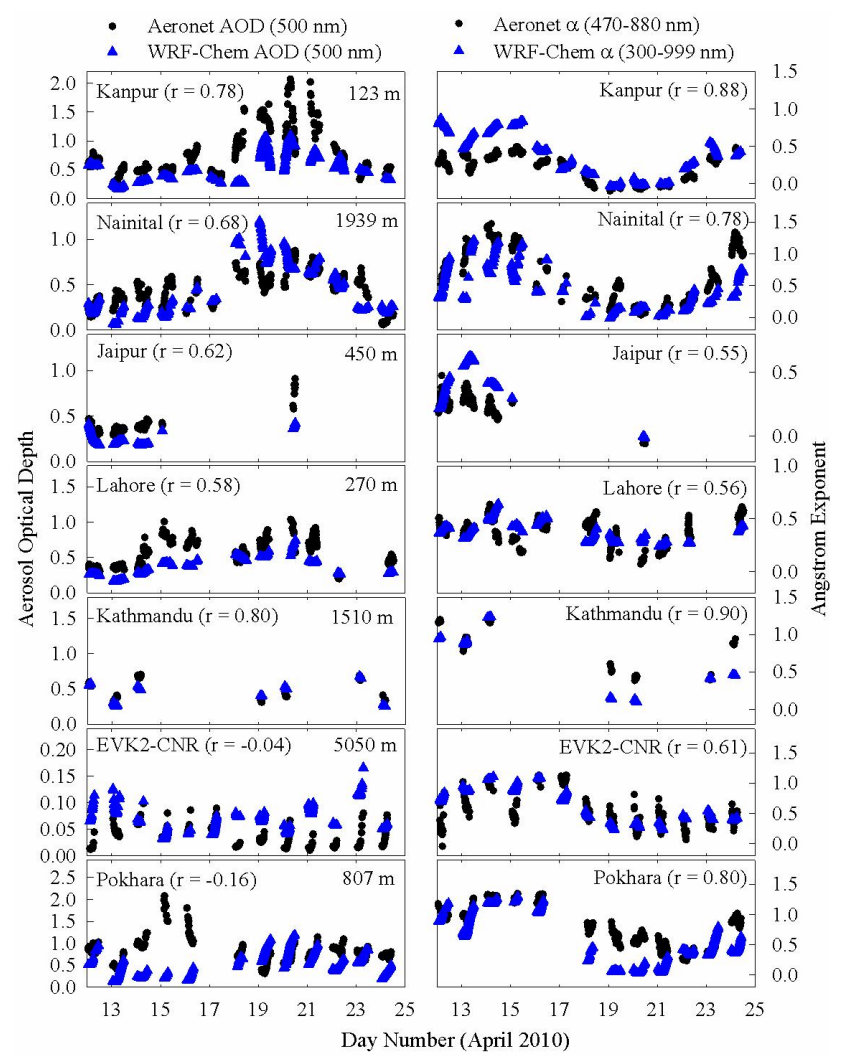

Fig. 8. Variations in co-located AERONET observed and WRFChem simulated aerosol optical depth at $550 \mathrm{~nm}$ (left panels) and Ångström exponent (right panels) at seven sites located in the model domain during 13-25 April 2010. The correlation coefficients $(r)$ are also shown for both the parameters at all the seven sites and numbers in the upper right corner of left panels represent the altitude of site.

( $N=42)$ and Pokhara $(N=26)$ during 13-25 April 2010. The column-averaged modeled and observed SSA values during 13-25 April 2010 are estimated to be $0.877 \pm 0.006$ and $0.900 \pm 0.036(r=0.80)$ at Kanpur, $0.871 \pm 0.002$ and $0.929 \pm 0.027(r=0.72)$ at Nainital, $0.877 \pm 0.004$ and $0.916 \pm 0.018(r=0.43)$ at Lahore, and $0.877 \pm 0.002$ and $0.847 \pm 0.029(r=0.21)$ at Pokhara, respectively. The underestimation of SSA by WRF-Chem suggests that model aerosols are slightly more absorbing than the observed aerosols, except at Pokhara where they are more scattering.

Satellite observations of AOD and aerosol index are used to examine the dust storm-induced changes in aerosol properties on a regional scale. The spatial distributions of aerosol optical depth at $550 \mathrm{~nm}$ retrieved by SeaWiFS and MODIS, and the OMI retrieved ultraviolet aerosol index during 13-16 April and 17-22 April 2010 are shown in Fig. 9. The periods of 13-16 April and 17-22 April 2010 represent periods of low and high dust emissions, respectively (Fig. 1c). AOD retrievals from both the satellites show similar spatial structure $(r=0.75)$ during both low and high dust emission 

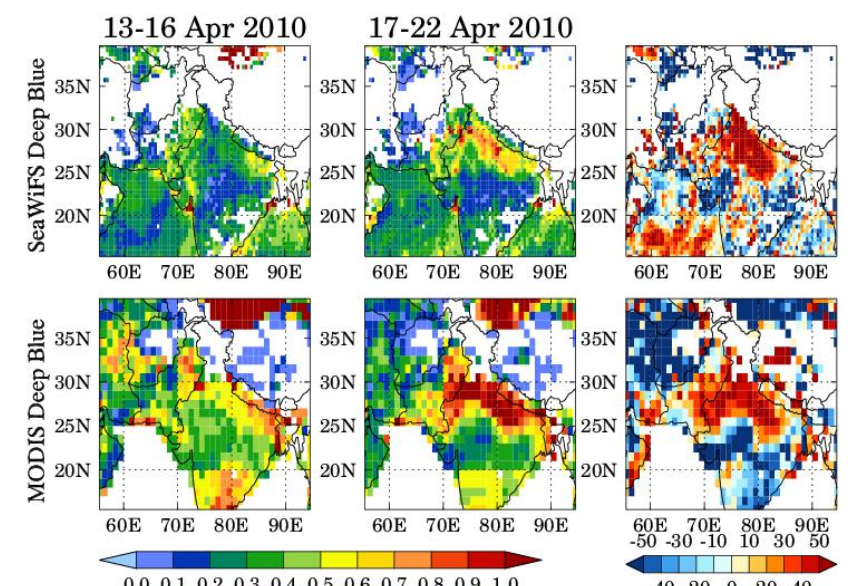

$\begin{array}{lllllllllll}0.0 & 0.1 & 0.2 & 0.3 & 0.4 & 0.5 & 0.6 & 0.7 & 0.8 & 0.9 & 1.0\end{array}$ Aerosol Optical Depth

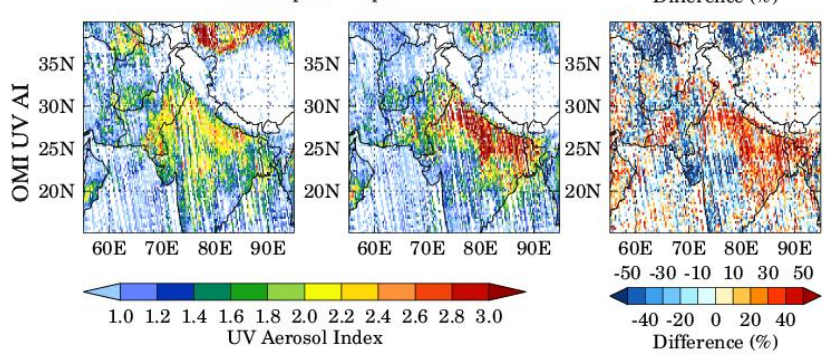

Fig. 9. Spatial distributions of aerosol optical depth at $550 \mathrm{~nm}$ from SeaWiFS at $0.5^{\circ} \times 0.5^{\circ}$ (top panels) and MODIS aboard Aqua at $1^{\circ} \times 1^{\circ}$ (middle panels), and OMI UV aerosol index at $0.25^{\circ} \times 0.25^{\circ}$ (bottom panels) during 13-16 April 2010 (low dust period) and 17-22 April 2010 (high dust period). The percentage changes in aerosol properties during high dust period relative to low dust periods are shown in rightmost middle and bottom panels.

periods and an increase of more than $50 \%$ between the period with low (0.2 to 0.4$)$ and the period with high (0.5 to more than 1) dust emissions over the Thar Desert and western IGP region. MODIS and SeaWiFS show similar relative changes, but AOD from SeaWiFS is only about half of the value retrieved by MODIS, indicating the large uncertainty in satellite AOD retrievals. The OMI UV aerosol index also shows an increase of more than $50 \%$ between the low and high dust emission period, indicating increased abundance of absorbing aerosols. Agricultural crop residue burning might also be an important source of absorbing aerosols during the pre-monsoon season in northern India (Kumar et al., 2011). However, the analysis of MODIS fire counts suggests low biomass burning activity over this region (http://firms.modaps.eosdis.nasa.gov/firemap/) during 17-22 April 2010, and thus enhancement in aerosol index is likely due to increase in dust aerosols. The presence of biomass burning aerosols is also ruled out by sharp decrease in $\alpha$ values during this period.

The ability of WRF-Chem in simulating the spatial distribution of AOD during low and high dust emission periods is also examined by comparing the model results with co-

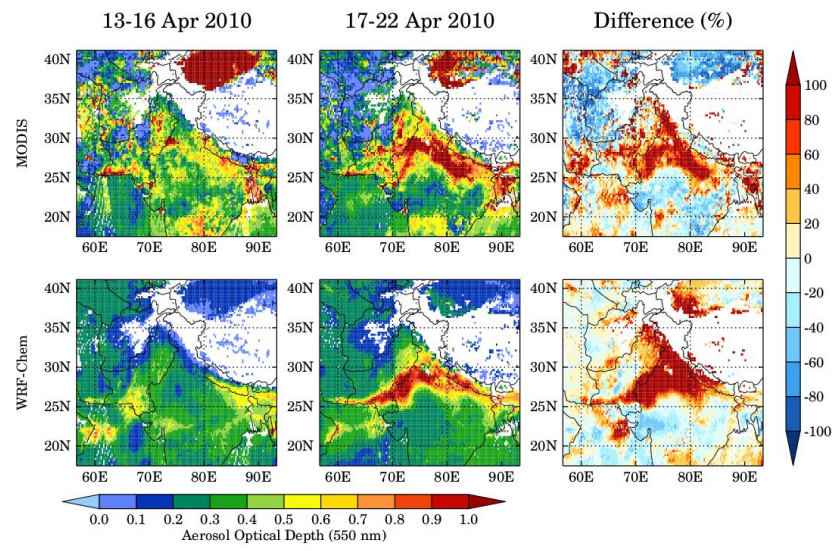

Fig. 10. Spatial distributions of aerosol optical depth at $550 \mathrm{~nm}$ retrieved by MODIS aboard Aqua (top panels) and simulated by WRF-Chem (bottom panels) during 13-16 April (low dust period) and 17-22 April 2010 (high dust period). Model results are colocated in space and time with MODIS retrievals and white space indicates missing data. MODIS AOD over land is from the "Deep Blue" algorithm and that over ocean is from the standard ocean algorithm. Percentage changes in AOD during high dust period relative to low dust period are shown in rightmost panels.

located Level 2 MODIS retrieved AOD at $550 \mathrm{~nm}$, as shown in Fig. 10. MODIS retrievals of AOD are used for evaluation because previous studies have shown that MODIS AOD compares well with in situ observations over the Indian region (Ramachandran, 2007; Sharma et al., 2012). The WRFChem model significantly underestimates MODIS-retrieved AOD during 13-16 April 2010 and even fails to capture the higher AOD values, particularly over the western IndoGangetic Plain region. This could be attributed to the uncertainties in anthropogenic aerosol emissions over the Indian region. It has been shown that current emission inventories lead to a drastic underestimation of BC aerosol over India (e.g., Nair et al., 2012). However, both the WRF-Chem and MODIS AOD show similar spatial distributions during 17-22 April 2010 with highest values over the Thar Desert and western IGP region, but the model still underestimates MODIS AOD retrievals outside these regions. Despite the differences in absolute magnitudes, the spatial distributions of percentage changes in AOD between high and low dust emission periods are similar with both of them showing an increase of more than $100 \%$ over the Thar Desert and western IGP and decrease of less than $50 \%$ over central India.

The MODIS and WRF-Chem AOD $(550 \mathrm{~nm})$ values averaged over the region of maximum dust influence $\left(70-80^{\circ} \mathrm{E}\right.$, $25-30^{\circ} \mathrm{N}$ ) during the low dust emission period are estimated as $0.48 \pm 0.19$ and $0.28 \pm 0.06$, respectively, and the corresponding average values during the high dust emission period are estimated as $0.80 \pm 0.30$ and $0.68 \pm 0.28$, respectively. The correlation coefficients over this region during the low and high dust emission periods are estimated as 0.14 and 0.58 , respectively. 


\subsection{Impact of dust storm on radiation budget}

The evaluation results presented in the above sections showed that the model underestimates the observed AOD values but is able to capture the temporal evolution of the dust storm and associated variations in aerosol optical properties, and thus provides confidence for using the model to understand the impact of this dust event on the radiation budget. We examine the radiative perturbation of dust aerosols on short-wave (SW), long-wave (LW) and net $(\mathrm{SW}+\mathrm{LW})$ radiation fluxes at the top of atmosphere (TOA) and the surface (SFC) by comparing two parallel simulations with and without dust aerosols. The difference between TOA and SFC radiative perturbations represents a change in radiation budget for the entire atmosphere and is termed atmospheric radiative perturbation (ATM). The net radiative fluxes (either SW or LW) at the SFC and TOA are calculated as the difference between down-welling and up-welling fluxes.

It has to be noted that the calculated atmospheric radiative perturbation does not equal a "radiative forcing" because the impact of aerosols on radiation may also affect the distribution of clouds as well as dynamics in the model and thus changes in the all-sky radiation budget could be due to both the aerosols and the clouds. However, use of analysis nudging in this study limits the impact of aerosols on model dynamics. The analysis of modeled cloud water mixing ratios shows a similar distribution of clouds between the dust and no-dust runs. It is also seen that there were very few clouds over the model domain during the simulation period, and those clouds that were simulated were located outside the region impacted by the dust storm. Therefore, the radiative changes reported here are expected to be close to the actual radiative forcing values.

The spatial distributions of diurnally averaged all-sky SW, LW and net radiative perturbation induced by dust aerosols during 17-22 April 2010 at the TOA, in the ATM and at the SFC are shown in Fig. 11. The spatial distributions of the dust radiative perturbation (either SW or LW or Net) are consistent with simulated distributions of dust, with highest values over the Thar Desert and western IGP region. The dust SW radiative perturbation at the TOA is generally negative over the model domain, except over the regions of higher surface albedo such as the Himalayan glaciers, the Thar Desert, and arid regions of Pakistan and Middle East. The SW radiative perturbation of dust at TOA depends strongly on the SW absorptivity of dust and generally has a cooling effect over the land regions for moderately absorbing dust (imaginary part of refractive index $=0.003$; Kalenderski et al., 2013), as is the case here.

The domain-averaged dust SW radiative perturbation at TOA is $-3.6 \pm 3.4 \mathrm{~W} \mathrm{~m}^{-2}$. The highest simulated instantaneous SW radiative perturbation at the surface reached $-70 \mathrm{~W} \mathrm{~m}^{-2}$ on 21 April 2010 in the Thar Desert. The WRFChem simulated diurnally averaged SW aerosol radiative perturbation at the TOA is compared with the radiative forc-

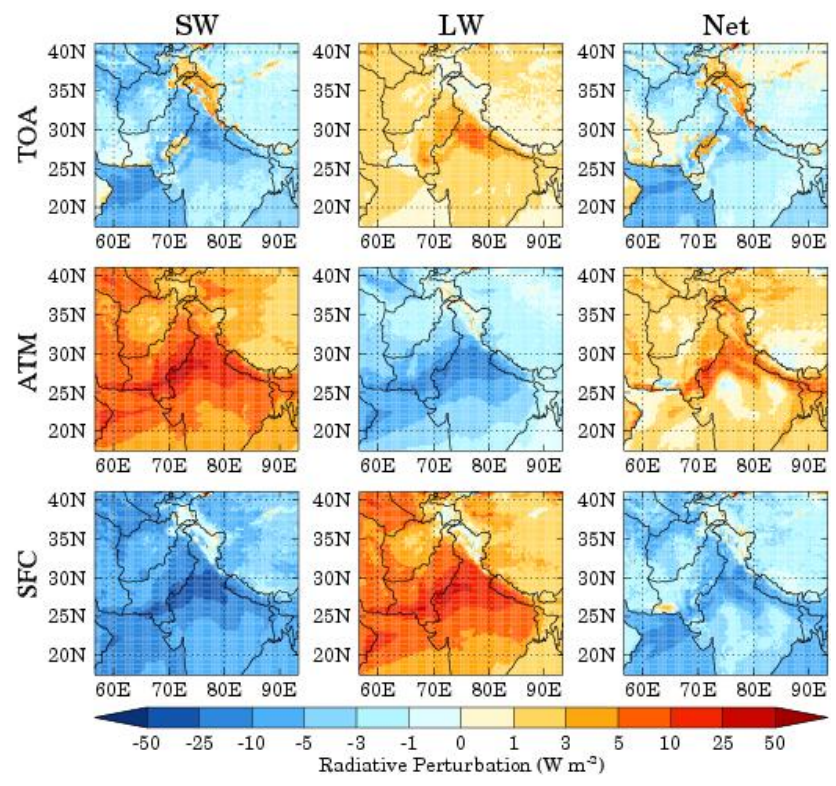

Fig. 11. Spatial distributions of diurnally averaged all-sky shortwave $(\mathrm{SW})$, long-wave $(\mathrm{LW})$ and $\mathrm{Net}(\mathrm{SW}+\mathrm{LW})$ radiative perturbation due to dust aerosols over the model domain from WRFChem simulations during 17-22 April 2010 at the top of atmosphere (TOA; top panels), in the atmosphere (ATM; middle panels) and at the surface (SFC; bottom panels). Positive values refer to an overall warming effect and negative values refer to an overall cooling effect. Radiative perturbation is calculated using two parallel simulations with and without dust.

ing estimates available for dusty days in the literature (Table 1). The WRF-Chem estimates at the TOA are similar to the observation-based estimates at Patiala and Kanpur but are much lower than those reported for Delhi. The differences at Delhi could be due to the difference in SW aerosol absorptivity, as WRF-Chem considers dust as moderately absorbing in the model while Pandithurai et al. (2008) used a strongly absorbing aerosol (mixture of dust and black carbon) with SSA of $0.74-0.84$ in their radiative transfer calculations. The LW radiative perturbation of dust at the TOA is generally small and has a domain-averaged value of $1.6 \pm 1.1 \mathrm{~W} \mathrm{~m}^{-2}$ with a maximum of $10.6 \mathrm{~W} \mathrm{~m}^{-2}$. The net $(\mathrm{SW}+\mathrm{LW})$ radiative perturbation of dust is thus controlled mostly by SW radiative effects and has a small cooling effect with an averaged value of $-2.9 \pm 3.1 \mathrm{~W} \mathrm{~m}^{-2}$ over the subregion of $\left(70-80^{\circ} \mathrm{E}\right.$, $\left.25-30^{\circ} \mathrm{N}\right)$. Similar values have been reported for the Arabian Peninsula and Red Sea $\left(-2.3 \mathrm{~W} \mathrm{~m}^{-2}\right.$ ) (Kalenderski et al., 2013). The analysis of vertical profiles of SW and LW heating rates (not shown) revealed that the dust-induced perturbations in radiation fluxes and heating rate are consistent with vertical distribution of dust and decrease as we move from the surface to higher altitudes. The changes in both SW and LW heating rates approaches zero near $6 \mathrm{~km}$.

The dust SW radiative perturbation in the atmosphere is positive throughout the model domain because dust absorbs 
Table 1. Comparison of WRF-Chem simulated radiative perturbation values with the available SW radiative forcing estimates at the top of the atmosphere (TOA) and the surface (SFC) at three sites in northern India.

\begin{tabular}{lrr|rr|rr}
\hline & \multicolumn{2}{c|}{ Patiala } & \multicolumn{2}{|c|}{ Kanpur } & \multicolumn{2}{c}{ Delhi } \\
& WRF-Chem & Observed $^{\mathrm{a}}$ & WRF-Chem & Observed $^{\mathrm{b}}$ & WRF-Chem & Observed $^{\mathrm{c}}$ \\
\hline TOA & -14.8 & -16.4 & -10.4 & -11 & -4 & -18.7 \\
SFC & -45.1 & -75.9 & -19 & -23 & -37.5 & -64 \\
\hline
\end{tabular}

a Sharma et al. (2012), ${ }^{\mathrm{b}}$ Prasad et al. (2007), ${ }^{\mathrm{c}}$ Pandithurai et al. (2008).

SW radiation and warms the atmosphere. The domainaveraged SW dust radiative perturbation in the atmosphere is $6.6 \pm 5.2 \mathrm{~W} \mathrm{~m}^{-2}$ with a maximum value of $41.1 \mathrm{~W} \mathrm{~m}^{-2}$. The LW radiative perturbation of dust has a cooling effect in the atmosphere with highest values over the Thar Desert $\left(-28.9 \mathrm{~W} \mathrm{~m}^{-2}\right)$. This is because of the hotter desert surface and strong interaction between LW radiation and coarse particles that remain confined to the source region due to their shorter atmospheric lifetimes. Overall, the net (SW + LW) radiative perturbation of dust has a small warming effect in the atmosphere with an average value of $5.1 \pm 3.3 \mathrm{~W} \mathrm{~m}^{-2}$ over the subregion of $\left(70-80^{\circ} \mathrm{E}, 25-30^{\circ} \mathrm{N}\right)$ and a maximum of $13.7 \mathrm{~W} \mathrm{~m}^{-2}$.

At the surface, the dust SW radiative perturbation has a cooling effect because dust aerosols attenuate the incoming radiation through absorption and scattering in the atmosphere. The modeled diurnally averaged SW dust radiative perturbation estimated at the surface is less than the observation-based estimates available for $\mathrm{Pa}$ tiala and Delhi but is similar for Kanpur (Table 1). The domain-averaged dust SW radiative perturbation at the surface is $-10.1 \pm 7.1 \mathrm{~W} \mathrm{~m}^{-2}$. This regional mean value of $-10.1 \mathrm{~W} \mathrm{~m}^{-2}$ is comparable to the values of SW dust radiative forcing at the surface reported for East Asia ( -8 to $-12 \mathrm{~W} \mathrm{~m}^{-2}$ ) (Han et al., 2011) and the Arabian Peninsula and Red Sea $\left(-6.0 \mathrm{~W} \mathrm{~m}^{-2}\right)$ (Kalenderski et al., 2013). The maximum value of simulated instantaneous SW radiative perturbation at the surface reached $-227 \mathrm{~W} \mathrm{~m}^{-2}$ on 21 April 2010 in the Thar Desert. The dust LW effect warms the surface by trapping LW radiation emitted by the Earth's surface, with a domain-averaged value of $5.8 \pm 5.0 \mathrm{~W} \mathrm{~m}^{-2}$ and highest warming over the Thar Desert $\left(31.8 \mathrm{~W} \mathrm{~m}^{-2}\right)$. The net $(\mathrm{SW}+\mathrm{LW})$ radiative perturbation of dust has a cooling effect at the surface and is $-8.0 \pm 3.3 \mathrm{~W} \mathrm{~m}^{-2}$ over the subregion of $\left(70-80^{\circ} \mathrm{E}, 25-30^{\circ} \mathrm{N}\right)$ and $-38.8 \mathrm{~W} \mathrm{~m}^{-2}$ on maximum.

The simulations with and without dust are also used to examine changes in the surface energy budget. Figure 12 shows the spatial distributions of changes in daytime (07:3018:30 IST), nighttime (18:30-07:30 IST) and $24 \mathrm{~h}$ average sensible heat flux, latent heat flux, $2 \mathrm{~m}$ temperature and planetary boundary layer (PBL) height. It has to be noted that analysis nudging was applied to temperature, water vapor and winds in the model simulations and thus changes shown

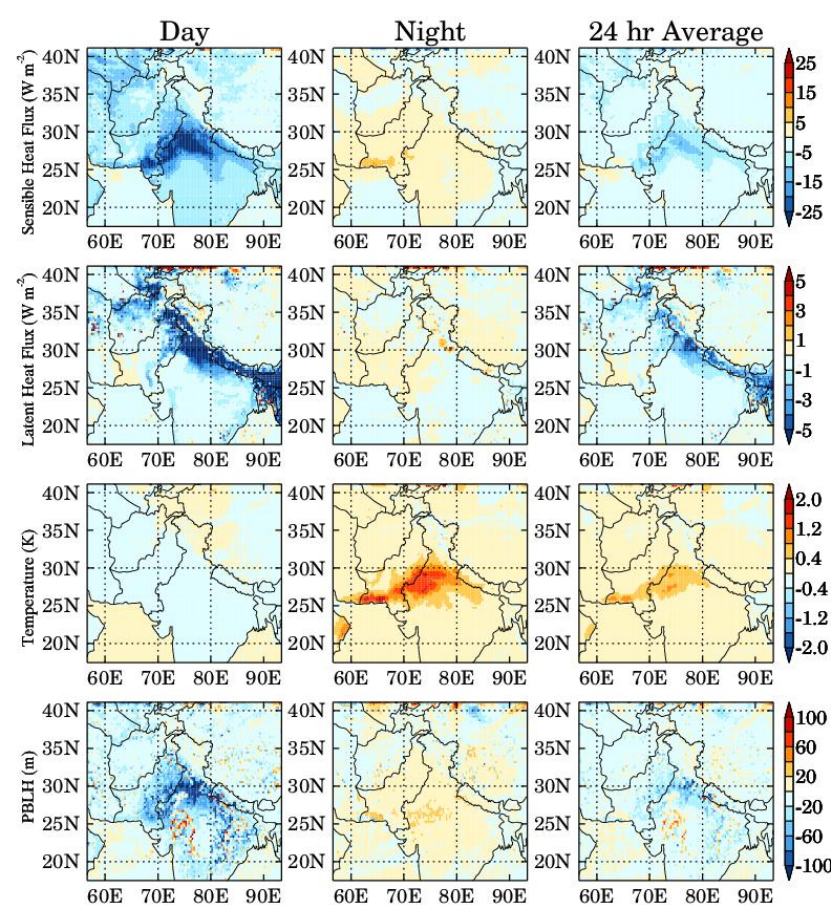

Fig. 12. Spatial distributions of changes in daytime (07:3018:30 IST), nighttime (18:30-07:30 IST) and $24 \mathrm{~h}$ average sensible heat flux, latent heat flux, $2 \mathrm{~m}$ temperature and planetary boundary layer height during 17-22 April 2010. The changes are calculated by comparing two parallel WRF-Chem simulations with and without dust.

here may not present the full response of radiative perturbations due to dust aerosols.

The heat fluxes, temperature and PBL height generally show a decrease during daytime and an increase during nighttime because of the dust loading, except latent heat flux, which shows a mixed response during nighttime. The changes are larger during daytime and smaller during nighttime except for temperature, for which the opposite is true. The larger increase in nighttime temperature over the Thar Desert is likely due to trapping of long-wave radiation by dust particles. Thus, the net effect of the dust storm on heat fluxes and PBL height are dominated by daytime responses and by nighttime responses in case of temperature. The dust storm-induced radiative perturbation is estimated to cause an 
overall small decrease of $-2.9 \pm 2.7 \mathrm{~W} \mathrm{~m}^{-2}$ in sensible heat flux, $-0.42 \pm 1.9 \mathrm{~W} \mathrm{~m}^{-2}$ in latent heat flux, $0.1 \pm 0.2 \mathrm{~K}$ in temperature and $-6.9 \pm 14.1 \mathrm{~m}$ in $24 \mathrm{~h}$ domain-average PBL height. However, changes can be locally significant and reach up to -69.4 and $-34.2 \mathrm{~W} \mathrm{~m}^{-2}$ in sensible and latent heat fluxes, $4.4 \mathrm{~K}$ in temperature and $-215.3 \mathrm{~m}$ in PBL height. These changes can have important implications for the stability and circulation of the lower atmosphere.

\section{Summary and conclusions}

This study presents an analysis of a typical pre-monsoon dust storm event in northern India that occurred during 1722 April 2010 by integrating available in situ (AERONET) and satellite based observations with WRF-Chem model results. The model predicted a total amount of $7.5 \mathrm{Tg}$ dust emitted during 17-22 April 2010 with values reaching as high as $2.1 \mathrm{Tg}$ on 20 April 2010. The dust storm and its impact on aerosol optical properties are captured by both in situ and satellite observations. Analysis of AERONET observations shows that Kanpur and Nainital are influenced the most by dust plumes where $500 \mathrm{~nm}$ AOD increased by more than $50 \%$ and Ångström exponent decreased by more than $70 \%$. The consistency of these changes in aerosol optical properties with general features of dust storm events reported for Kanpur (Dey et al., 2004; Prasad and Singh, 2007) indicate that this was a typical pre-monsoon season dust storm. Satellite observations show a substantial increase in the regional aerosol loading resulting in a $550 \mathrm{~nm}$ AOD increase of more than $50 \%$ over the Thar Desert and Indo-Gangetic Plain region due to increase in the abundance of absorbing aerosols.

We use the WRF-Chem model to understand the evolution and impact of this dust storm on the radiation and the surface energy budget. Analysis of modeled meteorology shows that this dust storm was generated by the presence of a low pressure area over the Indo-Gangetic Plain region that created high surface winds. WRF-Chem predicted domain-averaged daytime average total dust loadings of 21 and $19 \mathrm{~g} \mathrm{~m}^{-2}$ in the boundary layer and free troposphere, respectively, with $68-71 \%$ of the dust loading from coarse mode dust particles of 1.4 and $2.4 \mu \mathrm{m}$ effective raddi. The model is found to reproduce the observed variations in AOD, Ångström exponent and single scattering albedo well at most of the sites $(r=0.4$ to 0.8$)$. Model results clearly indicate this dust storm significantly influenced the regional radiation budget. The presence of dust aerosols reduced the regional solar radiation reaching the surface by on average $-10.1 \mathrm{~W} \mathrm{~m}^{-2}$ and increased the mean surface long wave radiation by $5.8 \mathrm{~W} \mathrm{~m}^{-2}$. The influence of dust particles on the top of atmosphere radiation was smaller with regional averages of -3.6 and $1.6 \mathrm{~W} \mathrm{~m}^{-2}$ for short- and long-wave radiative perturbation, respectively. However, the simulated instantaneous cooling under the dust plumes was much higher and reached -227 and $-70 \mathrm{~W} \mathrm{~m}^{-2}$ at the surface and the top of the atmosphere, respectively. The radiative perturbation due to dust aerosols averaged over the region (70$80^{\circ} \mathrm{E}, 25-30^{\circ} \mathrm{N}$ ) of maximum dust influence during $17-$ 22 April 2010 is estimated as $-2.9 \pm 3.1 \mathrm{~W} \mathrm{~m}^{-2}$ at the top of the atmosphere, $5.1 \pm 3.3 \mathrm{~W} \mathrm{~m}^{-2}$ in the atmosphere and $-8.0 \pm 3.3 \mathrm{~W} \mathrm{~m}^{-2}$ at the surface. Model results also show that radiative perturbation due to dust aerosols can cause significant changes locally in sensible $\left(-69.4 \mathrm{~W} \mathrm{~m}^{-2}\right)$ and latent $\left(-34.2 \mathrm{~W} \mathrm{~m}^{-2}\right)$ heat fluxes, $2 \mathrm{~m}$ temperature $(4.4 \mathrm{~K})$ and in PBL height $(-215.3 \mathrm{~m})$.

The accumulation of dust and black carbon aerosols over the IGP region and Himalayan foothills in northern India during the pre-monsoon season has been suggested to have important implications for the onset and advancement of the Indian summer monsoon (e.g., Lau et al., 2006). However, the models generally underestimate the AOD in this region and low dust emissions along with uncertainties in anthropogenic aerosol emissions are suggested to be responsible for this discrepancy (e.g., Cherian et al., 2012; Nair et al., 2012). The AERONET observations-based tuning of dust emissions presented in this study could be helpful for future studies focusing on modeling of aerosols in this region. Nevertheless, in situ observations of dust aerosols in the source as well as downwind regions are still highly essential for improving the regional dust emissions further. In addition to aerosol optical properties and radiation budget, dust aerosols can potentially affect tropospheric chemistry, and the impact of this April 2010 dust storm on tropospheric chemistry in northern India are addressed in a companion paper (Kumar et al., 2014).

Acknowledgements. We thank J. F. Lamarque and S. Madronich for their constructive suggestions on the manuscript, and the principal investigators and their staff for establishing and maintaining 7 AERONET sites used in this study. The data sets of initial and boundary conditions for meteorological fields are downloaded from http://dss.ucar.edu/datasets/ds083.2/data/. The data sets for initial and boundary conditions for chemical fields, biogenic emissions, biomass burning emissions and programs used to process these data sets are downloaded from the website http://www2.acd.ucar.edu/wrf-chem/. We thank the SeaWiFS, MODIS, OMI and CALIPSO science teams for providing the retrievals. The SeaWiFS, MODIS and OMI satellite products used in this study were acquired using the GES-DISC Interactive Online Visualization and Analysis Infrastructure (Giovanni). The National Center for Atmospheric Research is supported by the National Science Foundation. We thank the two reviewers for their comments.

Edited by: F. Fierli 


\section{References}

Beljaars, A. C. M.: The parameterization of surface fluxes in largescale models under free convection, Q. J. Roy. Meteor. Soc., 121, 255-270 1994.

Chaboureau, J.-P., Richard, E., Pinty, J.-P., Flamant, C., Di Girolamo, P., Kiemle, C., Behrendt, A., Chepfer, H., Chiriaco, M., and Wulfmeyer, V.: Long-range transport of Saharan dust and its radiative impact on precipitation forecast: a case study during the Convective and Orographically-induced Precipitation Study (COPS), Q. J. Roy. Meteor. Soc., 137, 236-251, doi:10.1002/qj.719, 2011.

Chen, F. and Dudhia, J.: Coupling and advanced land surface hydrology model with the Penn State-NCAR MM5 modelingsystem, Part I: Model implementation and sensitivity, Mon. Weather Rev., 129, 569-585, 2001.

Cherian, R., Venkataraman, C., Ramachandran, S., Quaas, J., and Kedia, S.: Examination of aerosol distributions and radiative effects over the Bay of Bengal and the Arabian Sea region during ICARB using satellite data and a general circulation model, Atmos. Chem. Phys., 12, 1287-1305, doi:10.5194/acp-12-12872012, 2012.

Chin, M., Ginoux, P., Kinne, S., Holben, B. N., Duncan, B. N., Martin, R. V., Logan, J. A., Higurashi, A., and Nakajima, T.: Tropospheric aerosol optical thickness from the GOCART model and comparisons with satellite and sunphotometer measurements, J. Atmos. Sci., 59, 461-483, 2002.

Chinnam, N., Dey, S., Tripathi, S. N., and Sharma, M.: Dust events in Kanpur, northern India: Chemical evidence for source and implications to radiative forcing, Geophys. Res. Lett., 33, L08803, doi:10.1029/2005GL025278, 2006.

Deng, A., Stauffer, D. R., Dudhia, J., Otte, T. L., and Hunter, G. K.: Update on analysis nudging FDDA in WRFARW, 8th WRF users workshop, Boulder, Colorado, USA, available at: http://www.mmm.ucar.edu/wrf/users/workshops/ WS2007/abstracts/4-8_Deng.pdf, (last access: 6 March 2014), 2006.

Dentener, F. J., Carmichael, G. R. , Zhang, Y., Lelieveld, J., and Crutzen, P. J.: Role of mineral aerosol as a reactive surface in theglobal troposphere, J. Geophys. Res, 101, 22869-22889, 1996.

Dey, S., Tripathi, S. N., Singh, R. P., and Holben, B. N.: Influence of dust storms on aerosol opticalproperties over the Indo-Gangetic basin, J. Geophys. Res., 109, D20211, doi:10.1029/2004JD004924, 2004.

Dipu, S., Prabha, T. V., Pandithurai, G., Dudhia, J., Pfister, G., Rajesh, K., and Goswami, B. N.: Impact of elevated dust aerosol layer on the cloud macrophysical properties prior to monsoon onset, Atmos. Environ., 70, 454-467, 2013.

Dubovik, O. and King, M. D.: A flexible inversion algorithm for retrieval of aerosol optical properties from Sun and sky radiance measurements, J. Geophys. Res., 105, 20673-20696, 2000.

El-Askary, H., Gautam, R., Singh, R., and Kafatos, M.: Dust storms detection over the Indo-Gangetic Basin using multi sensor data, Adv. Space Res., 37, 728-733, doi:10.1016/j.asr.2005.03.134, 2006.

Emmons, L. K., Walters, S., Hess, P. G., Lamarque, J.-F., Pfister, G. G., Fillmore, D., Granier, C., Guenther, A., Kinnison, D., Laepple, T., Orlando, J., Tie, X., Tyndall, G., Wiedinmyer, C., Baughcum, S. L., and Kloster, S.: Description and evaluation of the Model for Ozone and Related chemical Tracers, version 4
(MOZART-4), Geosci. Model Dev., 3, 43-67, doi:10.5194/gmd3-43-2010, 2010.

Fast, J. D, Gustafson Jr., W. I., Easter, R. C., Zaveri, R. A., Barnard, J. C., Chapman, E. G., and Grell, G. A.: Evolution of ozone,particulates, and aerosol direct forcing in an urban area using anew fully-coupled meteorology, chemistry, and aerosol model, J.Geophys. Res., 111, D21305, doi:10.1029/2005JD006721, 2006.

Freitas, S. R., Longo, K. M., Chatfield, R., Latham, D., Silva Dias, M. A. F., Andreae, M. O., Prins, E., Santos, J. C., Gielow, R., and Carvalho Jr., J. A.: Including the sub-grid scale plume rise of vegetation fires in low resolution atmospheric transport models, Atmos. Chem. Phys., 7, 3385-3398, doi:10.5194/acp-7-3385-2007, 2007.

Gautam, R., Liu, Z., Singh, R. P., and Hsu, N. C.: Two contrasting dust-dominant periods over India observed from MODIS and CALIPSO data, Geophys. Res. Lett., 36, L06813, doi:10.1029/2008GL036967, 2009.

Ge, J. M., Su, J., Ackerman, T. P., Fu, Q., Huang, J. P., and Shi, J. S.: Dust aerosol optical properties retrieval and radiativeforcing over northwestern China during the 2008 ChinaU.S. joint field experiment, J. Geophys. Res., 115, D00K12, doi:10.1029/2009JD013263, 2010.

Ghude, S. D., Pfister, G. G., Jena, C., van der A, R. J., Emmons, L. K., and Kumar, R: Satellite constraints of nitrogen oxide $\left(\mathrm{NO}_{\mathrm{X}}\right)$ emissions from India based on OMI observations and WRF-Chem simulations, Geophys. Res. Lett., 40, 2, 423-428, doi:10.1002/grl.50065, 2013.

Ginoux, P., Chin, M., Tegen, I., Prospero, J. M., Holben, B., Dubovik, O., and Lin, S. J.: Sources and distributions of dustaerosols simulated with the GOCART model, J. Geophys. Res.Atmos., 106, 20255-20273, 2001.

Granier, C. Bessagnet, B., Bond, T., D’Angiola, A., van der Gon, H. G., Frost, G. J., Heil, A., Kaiser, J. W., Kinne, S., Klimont, Z., Kloster, S., Lamarque, J.-F., Liousse, C., Masui, T., Meleux, F., Mieville, A., Ohara, T., Raut, J.-C., Riahi, K., Schultz, M. G., Smith, S. J., Thompson, A., van Aardenne, J., van der Werf, G. R., and van Vuuren, D. P.: Evolution of anthropogenic and biomass burning emissions of air pollutants at global and regional scales during the 1980-2010 period, Clim. Change, 109, 163-190, doi:10.1007/s10584-011-0154-1, 2011.

Grell, G. A., Peckham, S. E., Schmitz, R., McKeen, S. A., Frost, G., Skamarock, W. C., and Eder, B.: Fully coupled "online" chemistrywithin the WRF model, Atmos. Environ., 39, 6957-6975, 2005.

Guenther, A., Karl, T., Harley, P., Wiedinmyer, C., Palmer, P. I., and Geron, C.: Estimates of global terrestrial isoprene emissions using MEGAN (Model of Emissions of Gases and Aerosols from Nature), Atmos. Chem. Phys., 6, 3181-3210, doi:10.5194/acp-63181-2006, 2006.

Han, X., Zhang, M., Han, Z., Xin, J., and Liu, X.: Simulation of aerosol direct radiative forcing with RAMSCMAQin East Asia, Atmos. Environ., 45, 6576-6592, doi:10.1016/j.atmosenv.2011.08.006, 2011.

Haywood, J. and Boucher, O.: Estimates of the direct and indirect radiative forcing due to tropospheric aerosols: a review, Rev. Geophys., 38, 513-543, 2000.

Hegde, P., Pant, P., Naja, M., Dumka, U. C., and Sagar, R.: South Asian dust episode in June 2006: Aerosol observations 
in the central Himalayas, Geophys. Res. Lett., 34, L23802, doi:10.1029/2007GL030692, 2007.

Holben, B. N., Eck, T. F., Slutsker, I., Tanre, D., Buis, J. P.,Stezer, A., Vermote, E., Reagan, Y., Kaufman, U. J., Nakajima, T.,Lavenu, F., Jankowiak, I., and Smirnov, A.: AERONET-A federatedinstrument network and data archive for aerosol characterization, Remote Sens. Environ., 66, 1-16, 1998.

Hong, S.-Y., Yign, N., and Dudhia, J.: A new vertical diffusion package with an explicit treatment of entrainment processes, Mon. Weather Rev., 134, 2318-2341, 2006.

Hsu, N. C., Tsay, S. C., King, M. D., and Herman, J. R.: Aerosol properties over bright-reflecting source regions, IEEE T. Geosci. Remote, 42, 557-569, doi:10.1109/TGRS.2004.824067, 2004.

Huneeus, N., Schulz, M., Balkanski, Y., Griesfeller, J., Prospero, J., Kinne, S., Bauer, S., Boucher, O., Chin, M., Dentener, F., Diehl, T., Easter, R., Fillmore, D., Ghan, S., Ginoux, P., Grini, A., Horowitz, L., Koch, D., Krol, M. C., Landing, W., Liu, X., Mahowald, N., Miller, R., Morcrette, J.-J., Myhre, G., Penner, J., Perlwitz, J., Stier, P., Takemura, T., and Zender, C. S.: Global dust model intercomparison in AeroCom phase I, Atmos. Chem. Phys., 11, 7781-7816, doi:10.5194/acp-11-7781-2011, 2011.

Jickells, T. D., An, Z. S., Andersen , K. K., Baker, A. R., Bergametti, G., Brooks, N., Cao, J. J., Boyd, P. W., Duce, R. A.,Hunter, K. A., Kawahata, H., Kubilay, N., laRoche, J., Liss, P.S., Mahowald, N., Prospero, J. M., Ridgwell, A. J., Tegen, I., and Torres, R.: Global iron connections between desert dust, ocean biogeochemistry and climate, Science, 308, 67-71, 2005.

Kain, J. S.: The Kain-Fritsch convective parameterization: An update, J. Appl. Meteorol., 43, 170-181, 2004.

Kalenderski, S., Stenchikov, G., and Zhao, C.: Modeling a typical winter-time dust event over the Arabian Peninsula and the Red Sea, Atmos. Chem. Phys., 13, 1999-2014, doi:10.5194/acp-131999-2013, 2013.

Kaufman, Y. J., Tanre, D., Remer, L. A., Vermote, E. F., Chu, A., and Holben, B. N.: Operational remote sensing of troposphericaerosol over land from EOS moderate resolution imaging spectroradiometer, J. Geophys. Res., 102, 17051-17067, 1997.

Kumar, R., Naja, M., Satheesh, S. K., Ojha, N., Joshi, H., Sarangi, T., Pant, P., Dumka, U. C., Hegde, P., and Venkataramani, S.: Influences of the springtime northern Indian biomass burning over the central Himalayas, J. Geophys. Res., 116, D19302, doi:10.1029/2010JD015509, 2011.

Kumar, R., Naja, M., Pfister, G. G., Barth, M. C., and Brasseur, G. P.: Simulations over South Asia using the Weather Research and Forecasting model with Chemistry (WRF-Chem): set-up and meteorological evaluation, Geosci. Model Dev., 5, 321-343, doi:10.5194/gmd-5-321-2012, 2012a.

Kumar, R., Naja, M., Pfister, G. G., Barth, M. C., Wiedinmyer, C., and Brasseur, G. P.: Simulations over South Asia using the Weather Research and Forecasting model with Chemistry (WRFChem): chemistry evaluation and initial results, Geosci. Model Dev., 5, 619-648, doi:10.5194/gmd-5-619-2012, 2012 b.

Kumar, R., Barth, M. C., Madronich, S., Naja, M., Carmichael, G. R., Pfister, G. G., Knote, C., Brasseur, G. P., Ojha, N., and Sarangi, T.: Effects of dust aerosols on tropospheric chemistry during a typical pre-monsoon season dust storm in northern India, Atmos. Chem. Phys. Discuss., 14, 1113-1158, doi:10.5194/acpd-14-1113-2014, 2014.
Lau, K. M., Kim, M. K., and Kim, K. M.: Asian summer monsoon anomalies induced by aerosol direct forcing: The role of the Tibetan Plateau, Clim. Dynam., 26, 855-864, doi:10.1007/s00382006-0114-z, 2006

Li, F., Ginoux, P., and Ramaswamy, V.: Distribution, transport, and deposition of mineral dust in the Southern Ocean and Antarctica: Contribution of major sources, J. Geophys. Res., 113, D10207, doi:10.1029/2007JD009190, 2008.

Lo, J. C.-F., Yang, Z.-L., and Pielke Sr., R. A.: Assessment of three dynamical climate downscaling methods using the Weather Researchand Forecasting (WRF) model, J. Geophys. Res., 113, D09112, doi:10.1029/2007JD009216, 2008.

Mahowald, N. M., Baker, A. R., Bergametti, G., Brooks, N., Duce, R. A., Jickells, T. D., Kubilay, N., Prospero, J. M., and Tegen, I.: Atmospheric global dust cycle and iron inputs to the ocean, Global Biogeochem. Cy., 19, GB4025, doi:10.1029/2004GB002402, 2005.

Miller, R. L., Tegen, I., and Perlwitz, J.: Surface radiative forcing by soil dust aerosols and the hydrologic cycle, J. Geophys. Res., 109, D04203, doi:10.1029/2003JD004085, 2004.

Mlawer, E. J., Taubman, S., Brown, P., Iacono, M., and Clough, S.: Radiative transfer for inhomogenous atmosphere: RRTM, avalidated correlated-k model for the long-wave, J. Geophys. Res., 102, 16663-16682, doi:10.1029/97JD00237, 1997.

Nair, V. S., Moorthy, K. K., Alappattu, D. P., Kunhikrishnan, P. K., George, S., Nair, P. R., Babu, S. S., Abish, B., Satheesh, S. K., Tripathi, S. N., Niranjan, K., Madhavan, B. L., Srikant, V. K., Dutt, C. B. S., Badrinath, K. V. S., and Reddy, R. R.: Wintertime aerosol characteristics over the Indo-Gangetic Plain (IGP): Impacts of local boundary layer processes and long-range transport, J. Geophys. Res., 112, D13205, doi:10.1029/2006JD008099, 2007.

Nair, V. S., Solmon, F., Giorgi, F., Mariotti, L., Babu, S. S., and Moorthy, K. K.: Simulation of South Asian aerosols for regional climate studies, J. Geophys. Res., 117, D04209, doi:10.1029/2011JD016711, 2012.

Pandithurai, G., Dipu, S., Dani, K. K.,Tiwari, S., Bisht, D. S., Devara, P. C. S., and Pinker, R. T.: Aerosol radiative forcing during dust events over New Delhi, India, J. Geophys. Res., 113, D13209, doi:10.1029/2008JD009804, 2008.

Pfister, G. G., Parrish, D. D., Worden, H., Emmons, L. K., Edwards, D. P., Wiedinmyer, C., Diskin, G. S., Huey, G., Oltmans, S. J., Thouret, V., Weinheimer, A., and Wisthaler, A.: Characterizing summertime chemical boundary conditions for airmasses entering the US West Coast, Atmos. Chem. Phys., 11, 1769-1790, doi:10.5194/acp-11-1769-2011, 2011.

Prasad, A. K. and Singh, R. P.: Changes in aerosol parameters during major dust storm events (2001-2005) over the Indo-Gangetic Plains using AERONET and MODIS data, J. Geophys. Res., 112, D09208, doi:10.1029/2006JD007778, 2007.

Prasad, A. K., Singh, S., Chauhan, S. S., Srivastava, M. K., Singh, R. P., and Singh, R.: Aerosol radiative forcing over the IndoGangetic Plains during major storms, Atmos. Environ., 41, 6289-6301, 2007.

Prospero, J. M. and Lamb, J. P.: African droughts and dust transport to the Caribbean: Climate change and implications, Science, 302 , 1024-1027, 2003.

Prospero, J. M., Ginoux, P., Torres, O., Nicholson, S. E., and Gill, T. E.: Environmental characterization of global sources of 
atmospheric soil dust identified with the Nimbus 7 Total ozone Mapping Spectrometer (TOMS) absorbing aerosol product, Rev. Geophys., 40, 1002, doi:10.1029/2000RG000095, 2002.

Prospero, J. M., Landing, W. M., and Schulz, M.: African dust deposition to Florida: Temporal and spatial variability and comparisons to models, J. Geophys. Res.-Atmos., 115, D13304, doi:10.1029/2009jd012773, 2010.

Ramachandran, S.: Aerosol optical depth and fine mode fraction variations deduced from Moderate Resolution Imaging Spectroradiometer (MODIS) over four urban areas in India, J. Geophys. Res., 112, D16207, doi:10.1029/2007JD008500, 2007.

Reichler, T., Dameris, M., and Sausen, R.: Determining the tropopause height from gridded data, Geophys. Res. Lett., 30, 2042, doi:10.1029/2003GL018240, 2003.

Satheesh, S. K. and Moorthy, K. K.: Radiative effects of natural aerosols, A review, Atmos. Environ., 39, 2089-2110, 2005.

Seethala, C., Pandithurai, G., Fast, J., Polade, S., Reddy, M., and Peckham, S.: Evaluating WRF-Chem multi-scale model in simulating aerosol radiative properties over the tropics - A case study over India, Mapan-J. Metrol. Soc. I., 26, 269-284, doi:10.1007/s12647-011-0025-2, 2011.

Seinfeld, J. H., Carmichael, G., Arimoto, R., Conant, W. C., Brechtel, F. J., Bates, T. S., Cahill, T. A., Clarke, A. D., Doherty, S. J., Flatau, F. J., Huebert, B. J., Kim, J., Markowicz, K. M., Quinn, P. K., Russell, L. M., Russell, P. B., Shimizu, A., Y., Song, C. H., Tang, Y., Uno, I., Vogelmann, A. M., Weber, R. J., Woo, J., and Zhang, X. Y.: ACE-ASIA, Regional climatic and atmospheric chemical effects of Asian dust and pollution, B. Am. Meteorol. Soc., 85, 367-380, 2004.

Sharma, D., Singh, D., and Kaskaoutis, D. G.: Impact of Two Intense Dust Storms on Aerosol Characteristics and Radiative Forcing over Patiala, Northwestern India, Adv. Meteor., 2012, 956814, doi:10.1155/2012/956814, 2012.

Sikka, D. R.: Desert climate and its dynamics, Curr. Sci. India, 72, 35-46, 1997.

Skamarock, W. C., Klemp, J. B., Dudhia, J., Gill, D. O., Barker, D. M., Wang, W., and Powers, J. G.: A description of the advancedresearch WRF version 2, NCAR Tech. Note, NCAR/TN468+STR, Natl. Cent. for Atmos. Res., Boulder, Colo, available at: http://wrf-model.org/wrfadmin/publications.php, 2008.

Stanelle, T., Vogel, B., Vogel, H., Bäumer, D., and Kottmeier, C.: Feedback between dust particles and atmospheric processes over West Africa during dust episodes in March 2006 and June 2007, Atmos. Chem. Phys., 10, 10771-10788, doi:10.5194/acp10-10771-2010, 2010.

Tegen, I. and Fung, I.: Modeling of mineral dust in the atmosphere: Sources, transport, and optical thickness, J. Geophys. Res., 99, 22897-22914, doi:10.1029/94JD01928, 1994.

Teller, A., Xue, L., and Levin, Z.: The effects of mineral dust particles, aerosol regeneration and ice nucleation parameterizations on clouds and precipitation, Atmos. Chem. Phys., 12, 93039320, doi:10.5194/acp-12-9303-2012, 2012.

Textor, C., Schulz, M., Guibert, S., Kinne, S., Balkanski, Y., Bauer, S., Berntsen, T., Berglen, T., Boucher, O., Chin, M., Dentener, F., Diehl, T., Easter, R., Feichter, H., Fillmore, D., Ghan, S., Ginoux, P., Gong, S., Grini, A., Hendricks, J., Horowitz, L., Huang, P., Isaksen, I., Iversen, I., Kloster, S., Koch, D., Kirkevåg, A., Kristjansson, J. E., Krol, M., Lauer, A., Lamarque, J. F., Liu, X., Montanaro, V., Myhre, G., Penner, J., Pitari, G., Reddy, S., Seland,
Ø., Stier, P., Takemura, T., and Tie, X.: Analysis and quantification of the diversities of aerosol life cycles within AeroCom, Atmos. Chem. Phys., 6, 1777-1813, doi:10.5194/acp-6-1777-2006, 2006.

Thompson, G., Rasmussen, R. M., and Manning, K.: Explicit forecasts of winter precipitation using an improved bulk microphysicsscheme, Part I: Description and sensitivity analysis, Mon. Weather Rev., 132, 519-542, 2004.

Tompkins, A. M., Cardinali, C., Morcrette, J.-J., and Rodwell, M.: Influence of aerosol climatology on forecasts of the African Easterly Jet, Geophys. Res. Lett., 32, L10801, doi:10.1029/2004GL022189, 2005.

Uno, I., Wang, Z., Chiba, M., Chun, Y. S., Gong, S. L., Hara, Y., Jung, E., Lee, S. S., Liu, M., Mikami, M., Music, S., Nickovic, S., Satake, S., Shao, Y., Song, Z., Sugimoto, N., Tanaka, T., and Westphal, D. L.: Dust model intercomparison (DMIP) study overAsia: Overview, J. Geophys. Res.-Atmos., 111, D12213, doi:10.1029/2005JD006575, 2006.

Wang, K., Zhang, Y., Nenes, A., and Fountoukis, C.: Implementation of dust emission and chemistry into the Community Multiscale Air Quality modeling system and initial application to an Asian dust storm episode, Atmos. Chem. Phys., 12, 1020910237, doi:10.5194/acp-12-10209-2012, 2012.

Washington, R., Todd, M., Middleton, N. J., and Goudie, A. S.: Dust storm source areas determined by the Total Ozone Monitoring Spectrometer and surface observations, Ann. Assoc. Am. Geogr., 93, 297-313, 2003.

Wiedinmyer, C., Akagi, S. K., Yokelson, R. J., Emmons, L. K., AlSaadi, J. A., Orlando, J. J., and Soja, A. J.: The Fire INventory from NCAR (FINN): a high resolution global model to estimate the emissions from open burning, Geosci. Model Dev., 4, 625641, doi:10.5194/gmd-4-625-2011, 2011.

Winker, D. M., Tackett, J. L., Getzewich, B. J., Liu, Z., Vaughan, M. A., and Rogers, R. R.: The global 3-D distribution of tropospheric aerosols as characterized by CALIOP, Atmos. Chem. Phys., 13, 3345-3361, doi:10.5194/acp-13-3345-2013, 2013.

Zhang, Q., Streets, D. G., Carmichael, G. R., He, K. B., Huo, H., Kannari, A., Klimont, Z., Park, I. S., Reddy, S., Fu, J. S., Chen, D., Duan, L., Lei, Y., Wang, L. T., and Yao, Z. L.: Asian emissions in 2006 for the NASA INTEX-B mission, Atmos. Chem. Phys., 9, 5131-5153, doi:10.5194/acp-9-5131-2009, 2009.

Zhao, C., Liu, X., Leung, L. R., Johnson, B., McFarlane, S. A., Gustafson Jr., W. I., Fast, J. D., and Easter, R.: The spatial distribution of mineral dust and its shortwave radiative forcing over North Africa: modeling sensitivities to dust emissions and aerosol size treatments, Atmos. Chem. Phys., 10, 8821-8838, doi:10.5194/acp-10-8821-2010, 2010.

Zhao, C., Liu, X., Ruby Leung, L., and Hagos, S.: Radiative impact of mineral dust on monsoon precipitation variability over West Africa, Atmos. Chem. Phys., 11, 1879-1893, doi:10.5194/acp11-1879-2011, 2011. 